\title{
Coniacian sandstones from the North Sudetic Synclinorium revisited: palaeoenvironmental and palaeogeographical reconstructions based on trace fossil analysis and associated body fossils
}

\author{
Alina Chrząstek ${ }^{1 *}$, Monika Wypych ${ }^{2}$ \\ ${ }^{1}$ Institute of Geological Sciences, Wrocław University, Plac M. Borna 9, 50-204 Wrocław, Poland \\ ${ }^{2}$ Wrocław University, Plac Uniwersytecki 1, 50-137 Wrocław, Poland \\ *corresponding author, e-mail: alina.chrzastek@uwr.edu.pl
}

\begin{abstract}
The Coniacian quartz sandstones (Żerkowice Member, Rakowice Wielkie Formation) that crop out at quarries near Czaple-Nowa Wieś Grodziska (North Sudetic Synclinorium) contain a low-diversity assemblage of trace fossils: Gyrochorte isp., Ophiomorpha nodosa Lundgren, 1891, Ophiomorpha isp., Phycodes cf. curvipalmatum (Pollard, 1981), ?Phycodes isp., Planolites cf. beverleyensis (Billings, 1862), Thalassinoides paradoxicus Woodward, 1830 and ?Thalassinoides isp. Moreover, interesting compound burrow systems, here referred to as Thalassinoides-Phycodes cf. palmatus and ?Thalassinoides-Phycodes, were recognised at the Czaple Quarry. Additionally, ?Gyrochorte isp., Phycodes cf. flabellum (Miller and Dyer, 1878) and ?Treptichnus isp. were encountered at correlative levels in the Rakowice Małe Quarry. Some of these ichnotaxa have not been recorded previously from Coniacian sandstones of the Żerkowice Member. Additionally, in slabs of these sandstones, the gastropod Nerinea bicincta Bronn, 1836 and the bivalve Lima haidingeri Zittel, 1866 were found. These interesting finds, in particular the gastropods, were already noted from the study area in the first half of the twentieth century by Scupin (1912-1913). Ethologically, the trace fossil assemblage is represented by domichnia or domichnia/fodinichnia (Ophiomorpha, Thalassinoides), fodinichnia (Phycodes) and pascichnia (Gyrochorte, Planolites). The compound burrow systems (Thalassinoides-Phycodes) are interpreted as dwelling/feeding structures. The possible tracemakers are crustaceans (Ophiomorpha, Thalassinoides) or worm-like animals (annelids and other) (Planolites, ?Phycodes, Gyrochorte and ?Treptichnus). The assemblage of trace fossils is characteristic of the Skolithos ichnofacies and Cruziana ichnofacies, typical of shallow-marine settings. Ichnological studies, as well as the presence of accompanying fossils (bivalves, gastropods), confirm the palaeoenvironmental reconstruction of the Żerkowice Member sandstones by Leszczyński (2010). That author interpreted the Coniacian sandstones as bar and storm deposits laid down in a shallow epicontinental sea (mainly the foreshore-upper shoreface; up to the middle shoreface) under normal oxygenation and salinity, in soft substrate, above fair-weather wave base. The deposition of the Żerkowice Member sandstones is linked to a regression that started after uplift of the southeastern part of the North Sudetic Synclinorium.
\end{abstract}

Key words: ichnology, Upper Cretaceous, Sudetes Mountains, Żerkowice Member, foreshore, shoreface

\section{Introduction}

Quartz sandstones are well exposed in the North Sudetic Synclinorium (Fig. 1); they have been referred to as Upper Quadersandstein (Oberquader; see Scupin, 1912-1913) and belong to the Żerkowice Member of the Rakowice Wielkie Formation (Milewicz, 1985, 1997). Outcrops of these sandstones are situated in the eastern and central part of the North Sudetic Synclinorium (e.g., Rakowice Małe, 
Żerkowice, Żeliszów, Czaple, Nowa Wieś Grodziska; see Milewicz, 1997 and Figure 1 here). The present study was conducted at four quarries near the villages of Czaple and Nowa Wieś Grodziska (Figs 2-4). A low-diversity assemblage of trace fossils has been recognised: five ichnogenera, eight ichnospecies and two compound burrow systems. Additionally, three other ichnotaxa, previously unknown from Coniacian sandstones of the Żerkowice Member, were found in coeval levels at the Rakowice Małe Quarry (Figs 5D, 7H-I, 10C). The gastropod Nerinea bicincta Bronn, 1836 and the bivalve Lima haidingeri Zittel, 1866 were also encountered in the sandstone blocks (Fig. 10D-F). The blocks with gastropods probably were transported from an adjacent quarry of Coniacian sandstones (Żeliszów Quarry; Fig. 1), where these fossils occur in quarry faces (pers. comm., A.M. Sroka, 2016). Additionally, earlier reports of such specimens by Scupin (1912-1913) support this view. He recorded Lima haidingeri (pl. 14/1; text-figs. 42, 43) and Nerinea bicincta (pl. 4/1; 5/17) from the Coniacian at Żeliszów Quarry (former Giersdorf). Additionally, Lima haidingeri was described by this author from the Rakowice Małe Quarry (former Wenig-Rackwitz; pl. 12/9). In the collections of the Geological Museum of Wrocław University there are also gastropods Nerinea buchi Zekeli, 1852 (formerly Cerithium buchii Keferstein, 1828), now Nerinea bicincta Bronn, 1836 (see synonym list of Scupin, 1912-1913; compare also Tiedt, 1958) found by Drescher in 1867 (MGUWr-1592s) in the same outcrop (Żeliszów Quarry, "Giersdorf"; Fig. 10G). According to Kollmann (2014, references therein), Nerinea (Parasimploptyxis) bicinta is synonymous with Nerinea (Parasimploptyxis) buchi.

Recently, a new ichnogenus and ichnospecies, Rosarichnoides sudeticus, were proposed for a well-preserved crustacean burrow collected at Czaple Quarry (Chrząstek et al., 2018). Those authors also described inoceramids (Inoceramus kleini Müller, 1888, Inoceramus sp.) and starfish (Astropecten scupini Andert, 1934), which had been earlier reported by Scupin (1912-1913) from this site. The Coniacian sandstones of the Żerkowice Member that crop out at the Rakowice Małe Quarry, were also studied by Leszczyński (2010), who described Thalassinoides isp. and Ophiomorpha isp. from these deposits, as well as a richer assemblage of ichnogenera from the Santonian (Rakowice Małe Quarry). On the basis of trace fossils recovered and sedimentary structures, Leszczyński (2010) suggested that these deposits were laid down in the foreshore-upper shoreface. He also reported that the trace fossil assemblage at Żerkowice Quarry represented a wider spectrum of ethological categories and ichnodiversity than the one at Rakowice Małe Quarry (i.e., more horizontal burrows of Ophiomorpha and Thalassinoides). Leszczyński (2010, p. 6) proposed the middle shoreface (distal expression of the Skolithos ichnofacies) as possible palaeoenvironment for these deposits.

In comparison to Leszczyński's study (2010), the current note demonstrates that in the Coniacian sandstones (Żerkowice Member) at the Czaple-Nowa Wieś Grodziska quarries, a more diverse ichnoassemblage occurs (Gyrochorte, Ophiomorpha nodosa, Ophiomorpha isp., Phycodes cf. curvipalmatum, ?Phycodes isp., Planolites cf. beverleyensis, Thalassinoides paradoxicus, ?Thalassinoides isp., compound burrow systems Thalassinoides-Phycodes cf. palmatus, ?Thalassinoides-Phycodes) than at Rakowice Małe, from where only Ophiomorpha and Thalassinoides were described (Leszczyński, 2010). On the other hand, ?Gyrochorte isp., Phycodes cf. flabellum and ?Treptichnus isp. are here recorded for the first time from the Rakowice Małe Quarry.

The trace fossil assemblage described was visible mainly in the field on the surfaces of sandstone blocks. Some specimens were collected; these are housed in the collections of the Geological Museum of the University of Wrocław (MGUWr-6623s to $6631 \mathrm{~s})$.

The aim of the present paper is to document and describe all trace fossils (in some cases unknown earlier from the strata studied) found in the sandstones of the Żerkowice Member at Czaple and Nowa Wieś Grodziska quarries, as well as in the Rakowice Małe Quarry. Additionally, some body fossils (Nerinea bicincta, Lima haidingeri), found in the Czaple-Nowa Wieś Grodziska quarries (origin probably from the Żeliszów Quarry) and from the collections of the Geological Museum of the University of Wrocław (Nerinea buchi Zekeli, 1852 and Cyrena cretacea Drescher, 1863; MGUWR-1592s, 1542s; Fig. 10G-H), were also studied. The present study matches the sedimentological analysis of the Żerkowice Member by Leszczyński (2010). Here some data on the newly collected trace and body fossils (in particular those unknown previously from the Żerkowice Member) are added to the palaeoenvironmental and palaeogeographical interpretations.

\section{Geological setting}

The Czaple-Nowa Wieś Grodziska quarries are situated in the southern part of the North Sudetic Synclinorium (Sudetes Mountains, southwest Poland) in the Leszczyna-Jerzmanice halfgraben (Fig. 1). Boundaries of this geological unit include the Karkonosze-Izera Pluton, the Kaczawa Massif 


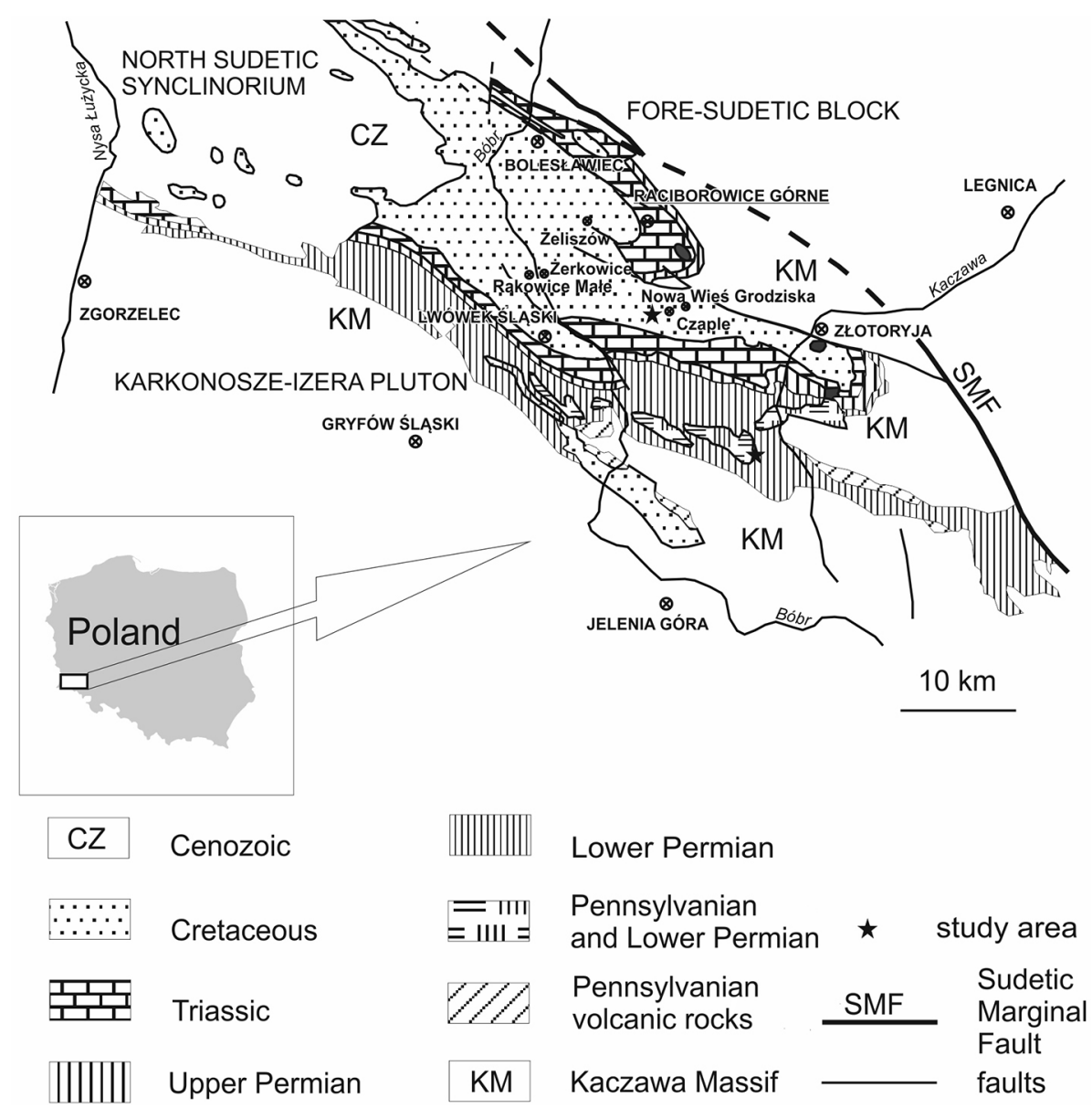

Fig. 1. Geological map of the North Sudetic Synclinorium.

(or Kaczawa Greenstone-and-Slate Fold Belt, see Żelaźniewicz et al., 2011) and the Fore-Sudetic Block.

Outcrops of the Upper Cretaceous rocks are found mostly in the central part of the North Sudetic Synclinorium, where the greatest thickness of these deposits was recorded, with Permian and Triassic strata along its northern and southern margins (Fig. 1). The North Sudetic Synclinorium is composed of two structural stages: the lower or basement, consisting of metamorphic rocks of the Kaczawa Massif, of ?Ediacaran to Mississippian age, and the upper or platform deposits (Late Palaeozoic-Mesozoic cover) ranging in age from Pennsylvanian to Late Cretaceous and Cenozoic (Baranowski et al., 1990; Kryza et al., 2007). The platform sediments (of Pennsylvanian, Permian, Triassic, Late Cretaceous and Cenozoic age) were folded and faulted during the Palaeogene (Żelaźniewicz \& Aleksandrowski, 2008). Upper Middle and Upper Triassic rocks are known only from boreholes (Milewicz, 1985; Chrząstek, 2002, 2013a; references therein). The entire Cretaceous sequence, from the middle Cenomanian to the middle Santonian, is $600-1,300 \mathrm{~m}$ thick (Baranowski et al., 1990; Milewicz, 1991; Walaszczyk, 2008; Greguš et al., 2013). The thickness of the Coniacian deposits, which consist mainly of marls and sandstones, is about $300 \mathrm{~m}$ (Milewicz, 1973).

The Upper Cretaceous sequence overlies Triassic deposits, i.e., lower and middle Buntsandstein in the south and Röt and Muschelkalk in the north. In some cases, especially in the Wlen Graben, it lies transgressively on older rocks, either Rotliegendes or Lower Palaeozoic strata (Gorczyca-Skała, 1977; Milewicz, 1997).

The Upper Cretaceous of the North Sudetic Synclinorium is subdivided into three formations: the Rakowice Wielkie Formation (Cenomanian-Coniacian), the Czerna Formation and the Wegliniec Formation (Santonian) (Milewicz, 1985, 1997). The Coniacian quartz sandstones that crop out at the Czaple-Nowa Wieś Grodziska quarries belong to the Żerkowice Member of the Rakowice Wielkie Formation (Milewicz, 1997; Śliwiński et al., 2003; Chrząstek et al., 2004).

The sandstones studied are fine to medium-grained, in some cases coarse-grained arenites. The thickness of individual beds, which dip towards the south and southeast (compare Leszczyński, 

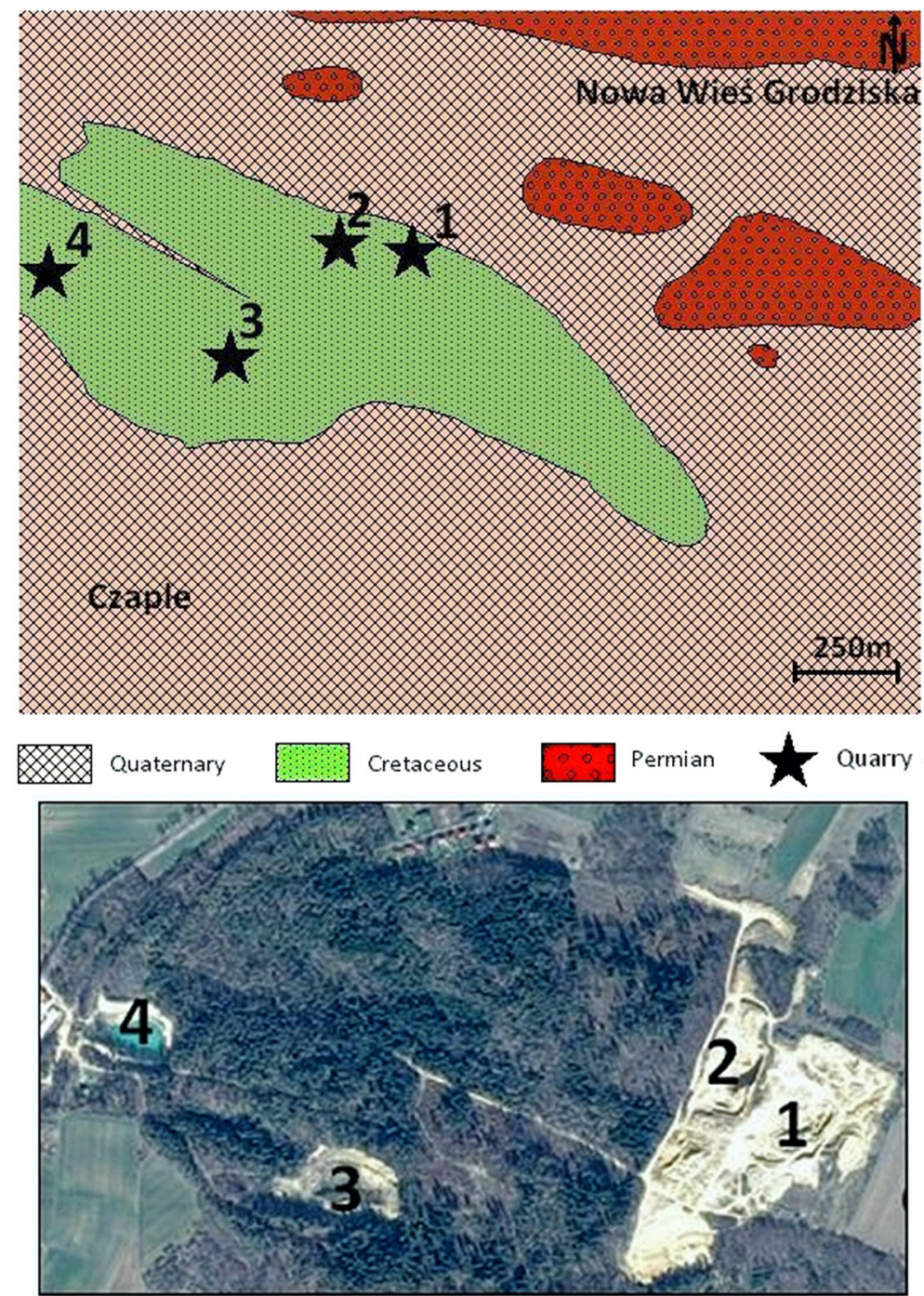

1, 2, 3, 4 Quarry

2010), attains up to a few metres (usually about 3 $\mathrm{m}$; Fig. 4A). The thickness of these deposits is up to $100 \mathrm{~m}$ (Milewicz, 1979). The sedimentary structures are poorly preserved in comparison to those in correlative deposits at the Rakowice Małe Quarry (see Fig. 4B), where trough cross-stratification, tabular cross-stratification and parallel stratification are visible (see also Leszczyński, 2010, fig. 5). These sandstones are mainly structureless or in some cases parallel lamination is marked (Fig. 4C) or poorly visible large-scale cross-stratification and ripple marks (Fig. 4C-E), especially in the upper part of the sections at the Nowa Wies Grodziska (Fig. 3; quarry 1) and Czaple quarries (Fig. 3; quarry 4$)$. They are well sorted, the best among the Upper Cretaceous sandstones from the North Sudetic Synclinorium, but their grains are poorly rounded (Milewicz, 1997; Leszczyński, 2010). In some cases, in the upper part of the section, these sandstones
Fig. 2. Geological sketch of the vicinity of the villages of Czaple and Nowa Wieś Grodziska. are covered with a ferric crust, particularly visible at the Nowa Wieś Grodziska Quarry (see also Leszczyński, 2010; Fig. 4A here). The quartz sandstones are interpreted as bar and storm deposits, which were mainly deposited in the foreshore/ upper shoreface (Leszczyński, 2010). The stratigraphy of the Upper Cretaceous deposits is based predominantly on inoceramid bivalves (Walaszczyk, 1992, 2008; Chrząstek, 2008; Walaszczyk \& Wood, in press), but also on other biota (e.g., foraminifera, cephalopods and echinoids; see Walaszczyk et al., 2016). According to Milewicz (1979, 1985, 1997), these sandstones are of early Coniacian age, a hiatus comprising the middle Coniacian. According to Walaszczyk (2008), the hiatus between Rakowice Wielkie Formation and overlying Czerna and Weggliniec formations comprised only a part of the middle Coniacian and the boundary between the former and the latter is placed in the middle/upper 
Quarry 1

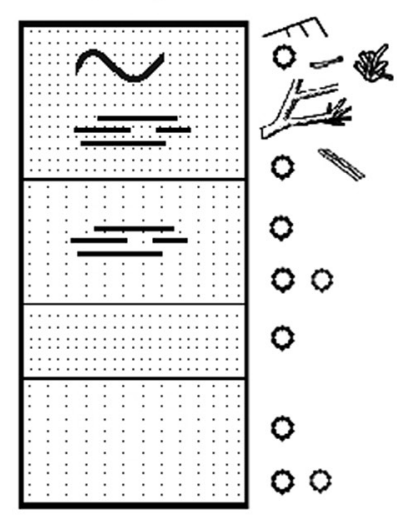

Quarry 3

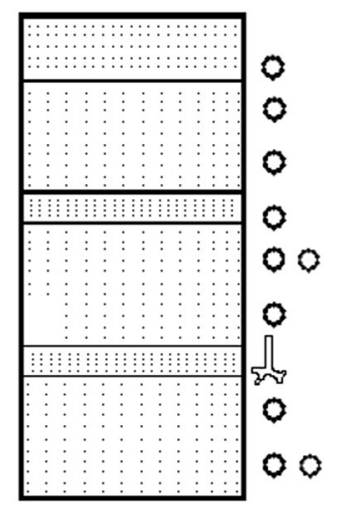

Quarry 4

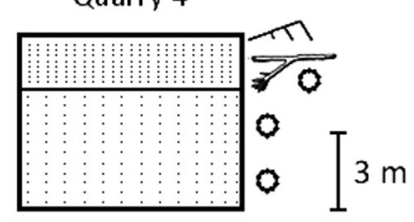

Fig. 3. Coniacian sections at Czaple-Nowa Wieś Grodziska quarries; 1-2: Nowa Wieś Grodziska; 3-4: Czaple.

Coniacian. Consequently, the boundary between the Coniacian and Santonian has been located in the middle part of the Czerna and Węgliniec formations (see discussion in Leszczyński, 2010).

Santonian deposits include mudstones, siltstones, sands and sandstones with plant roots, pieces of wood and amber, as well as intercalations of coal and kaoline (Alexandrowicz \& Kwiecińska, 1977; Leszczyński, 2010). These deposits are indicative of lacustrine, lagoonal, coastal and paludal environments and brackish bays, separated from the open sea by a sand barrier (see Leszczyński, 2010). In the collections of the Geological Museum of the University of Wrocław there are specimens of Cyrena cretacea found by Drescher in 1867 (MGUWr-1542s; Fig. $10 \mathrm{H}$ ) in the Upper Cretaceous of the Rakowice Małe Quarry (former Wenig-Rackwitz). These bivalves, typical of mesohaline conditions, were also recorded by Alexandrowicz (1976) and Milewicz (1988) from the Santonian of the North Sudetic Synclinorium. Earlier, Scupin (1912-1913, p. 166, text-fig. 23) had illustrated this bivalve species, encountered in the Rakowice Małe Quarry (Wenig-Rackwitz). Drescher (1863) also found Cyrena cretacea in the Upper Cretaceous of the North Sudetic Synclinorium (Lwówek Śląski, "Löwenberg"). Additionally, Scupin (19121913) documented in plates bivalves belonging to the genus Cyrena from the Żerkowice Quarry (former Sirgwitz; pl. 7/4, 6, 10).

In the collections of the Geological Museum of the University of Wrocław are also tree fern remains (genus Protopteris), probably from TuronianConiacian deposits of the North Sudetic Synclinorium (Żeliszów Quarry ["Giersdorf"] and Lwówek Śląski ["Löwenberg”]), which have recently been described by Greguš et al. (2013), who suggested that tree fern taxa were good indicators of climate and usually appeared in tropical forests.

The majority of trace fossils were observed in the field, on exposed rock surfaces. Some of them, e.g., ?Thalassinoides isp. and Ophiomorpha nodosa, plus the body fossils Lima haidingeri and Nerinea bicincta, were prepared from the rock and are now housed in the collections of the Geological Museum of the University of Wrocław (MGUWr-6623s-6631s).

\section{Systematic description of trace fossils}

\section{Gyrochorte Heer, 1865}

\section{Gyrochorte isp.}

Figs 4D, 5A-D

Material: Several specimens observed in the field on exposed surfaces of sandstone blocks at Czaple (Fig. 4D), Nowa Wieś Grodziska (Fig. 5A-C) and Rakowice Małe quarries (Fig. 5D).

Descripton: Straight or gently curved bilobate burrow, consisting of two convex lobes with a median furrow (positive relief; Fig. 5A, B) or two grooves with a median ridge (negative hyporelief; Fig. 5C). Specimens studied are $4.0-5.0 \mathrm{~mm}$ wide and $12-20$ cm long; burrows often cross cut and the median furrow is poorly visible (see Fig. 5D); for this reason, the latter specimens are assigned to Gyrochorte isp. with a query (as ?Gyrochorte isp.).

Remarks: These burrows show some similarities to material described by Gibert \& Benner (2002, figs 2-4) and Uchman \& Tchoumatchenco (2003, p. 29, fig. 3C). Heinberg \& Birkelund (1984) interpreted Gyrochorte as a combination of sediment-feeding 

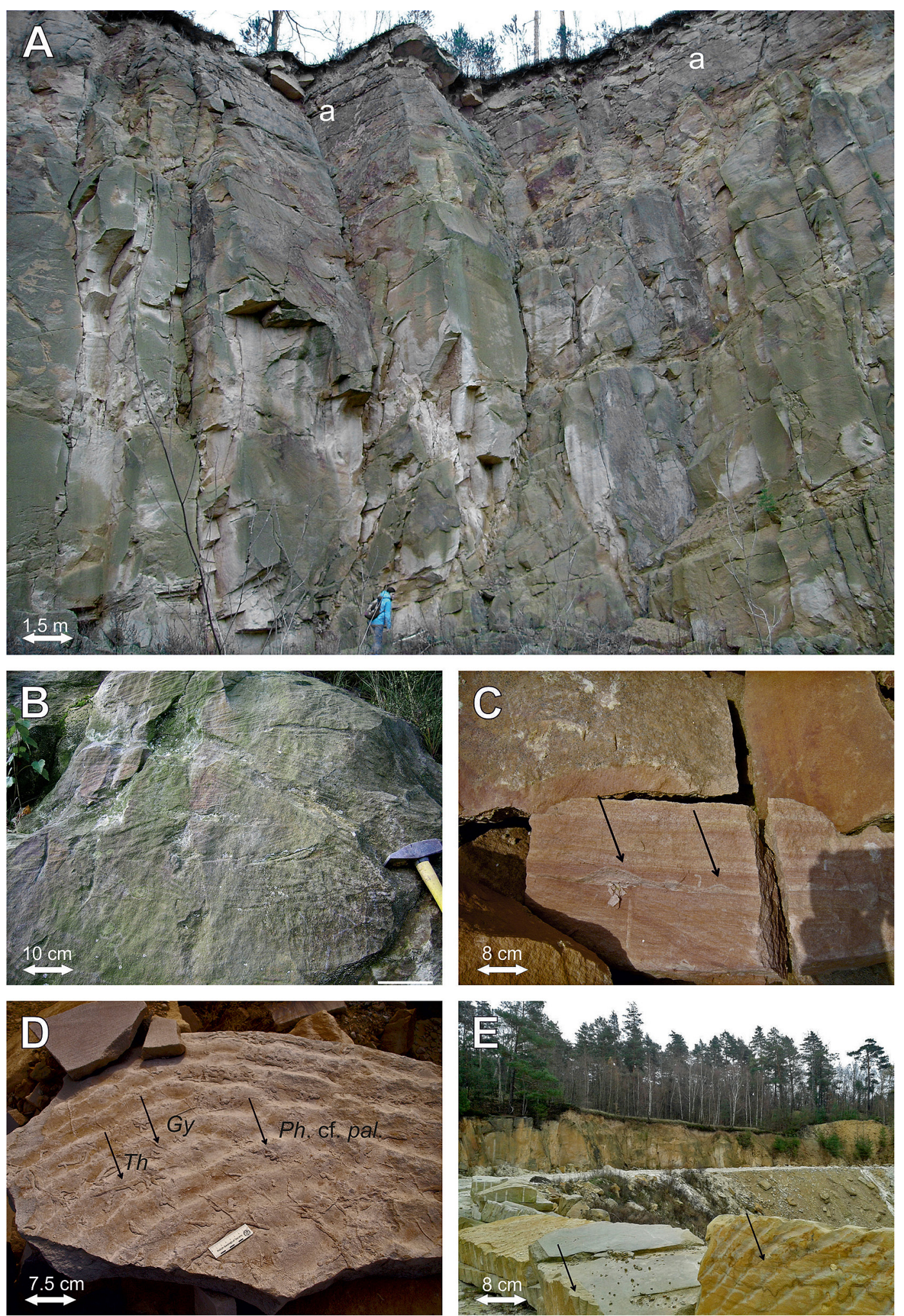

Fig. 4. Sedimentary structures. A - photograph of quartz sandstone at Czaple Quarry; a - ferric crust; B - trough cross-stratification, Rakowice Małe Quarry; C - planar cross-stratification and wave ripple marks, Czaple Quarry; arrows indicate ripple marks; D - ripple marks, Thalassinoides-Phycodes cf. palmatus; Thalassinoides (Th), Phycodes cf. palmatus (Ph. cf. pal.), Gyrochorte (Gy); specimens found by A. Kowalski (photograph by A. Kowalski) at Czaple Quarry; E - ripple marks, Czaple Quarry; arrows point to ripple marks. 

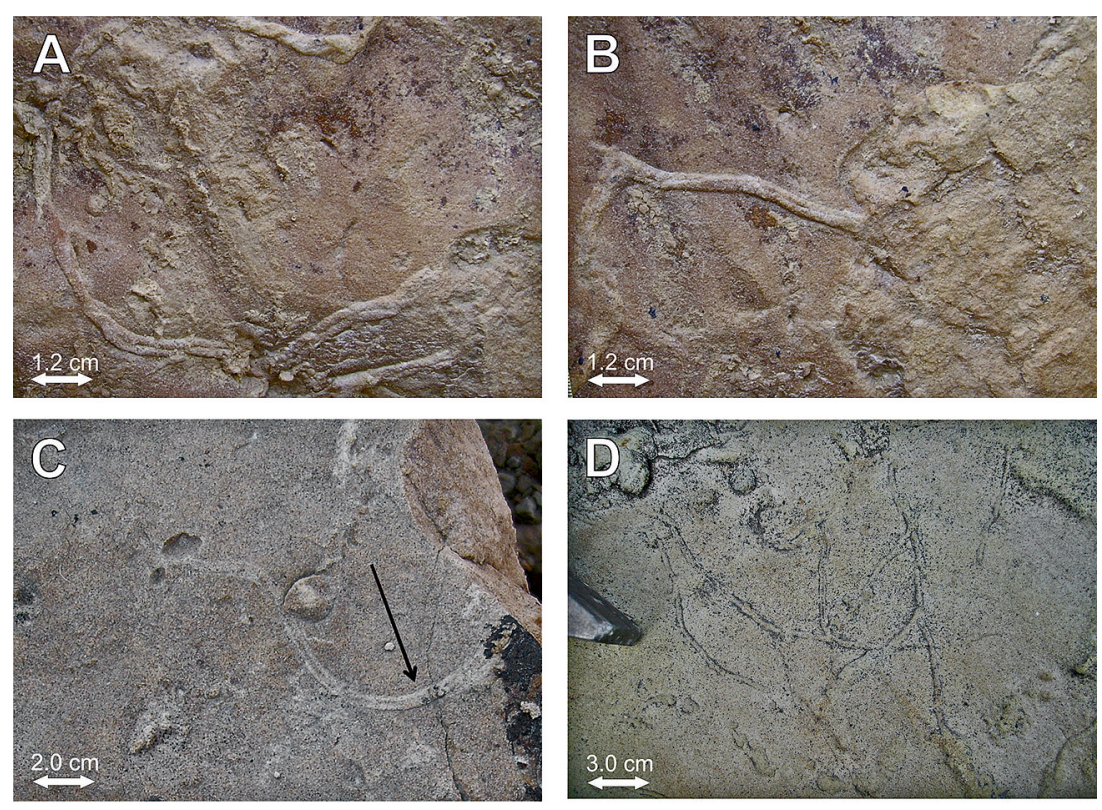

Fig. 5. Gyrochorte and Ophiomorpha. A-C - Gyrochorte isp., Nowa Wieś Grodziska; D - ?Gyrochorte isp., Rakowice Małe Quarry; E-F - Ophiomorpha nodosa, Nowa Wieś Grodziska Quarry, MGUWR-6623s-MGUWR-6624s; G Ophiomorpha nodosa, Nowa Wieś Grodziska Quarry; H - Ophiomorpha nodosa, swollen chamber, Nowa Wieś Grodziska Quarry. Arrows indicate trace fossils and swollen chamber of Ophiomorpha nodosa.
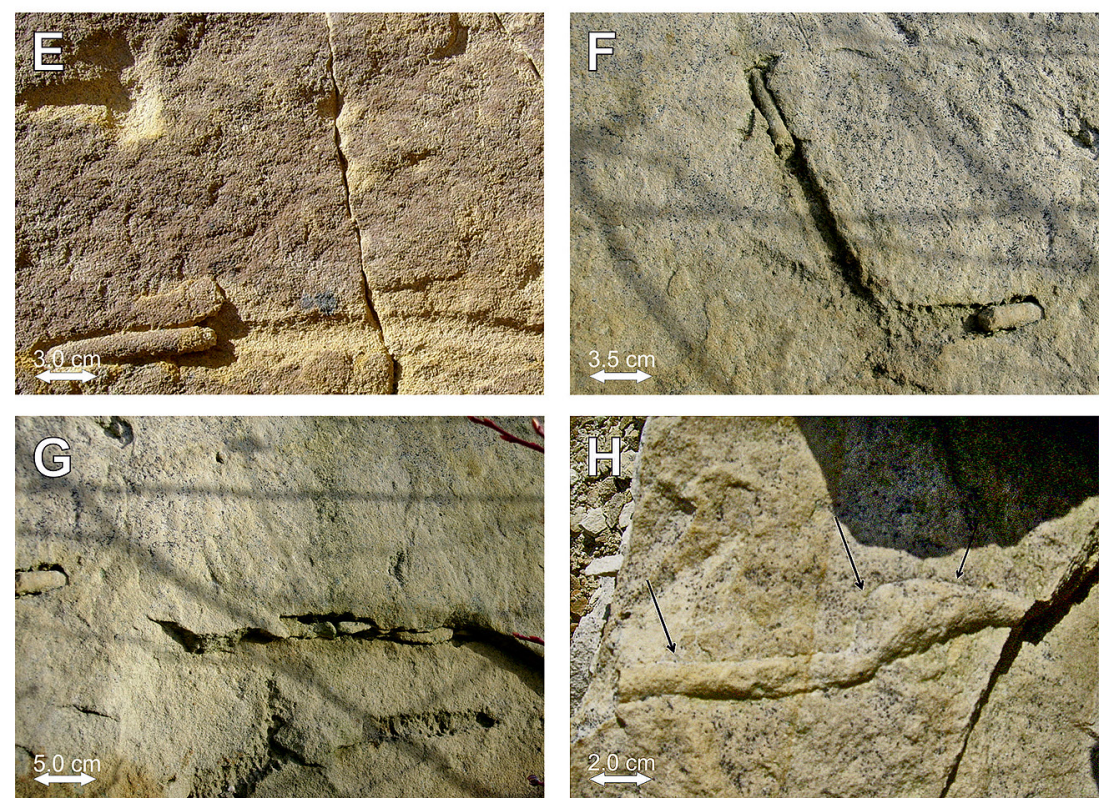

and locomotion (pascichnion). On the other hand, Mieras et al. (1993), Buatois \& Mángano (2011) and Minter et al. (2016) described this ichnotaxon as a locomotion trace (repichnion).

Tracemakers were deposit- or detritus-feeders, probably worm-like organisms (annelids) (Heinberg \& Birkelund, 1984; Gibert \& Benner, 2002; Gibert \& Ekdale, 2002; Fürsich et al., 2006). Gastropods or crustaceans have also been suggested as potential producers of Gyrochorte (Chen et al., 2011; Pazos et al., 2012; Bayet-Goll \& Neto de Carvalho, 2016; references therein). Schlirf (2000) regarded Gyrochorte as an arthropod trace (see also Uchman \& Tchoumatchenco, 2003).

This ichnotaxon is typical of the Cruziana ichnofacies (Fillion \& Pickerill, 1990). Gyrochorte usually occurs in shallow- and marginal, low- to moderate-energy marine settings (Gibert \& Benner, 2002). This ichnotaxon is common in foreshore/upper shoreface to lower shoreface settings (Mieras et al., 1993; Pemberton et al., 2001; Pearson et al., 2013) and its stratigraphical range is Ordovician to Pliocene (Gibert \& Benner, 2002).

\section{Ophiomorpha Lundgren, 1891}

\section{Ophiomorpha nodosa Lundgren, 1891}

Figs. 5E-H, 6A-H, 7A-F

Material: Forty specimens on quarry faces at Czaple-Nowa Wieś Grodziska, the majority of them on sandstone slabs. Some of them were collected 

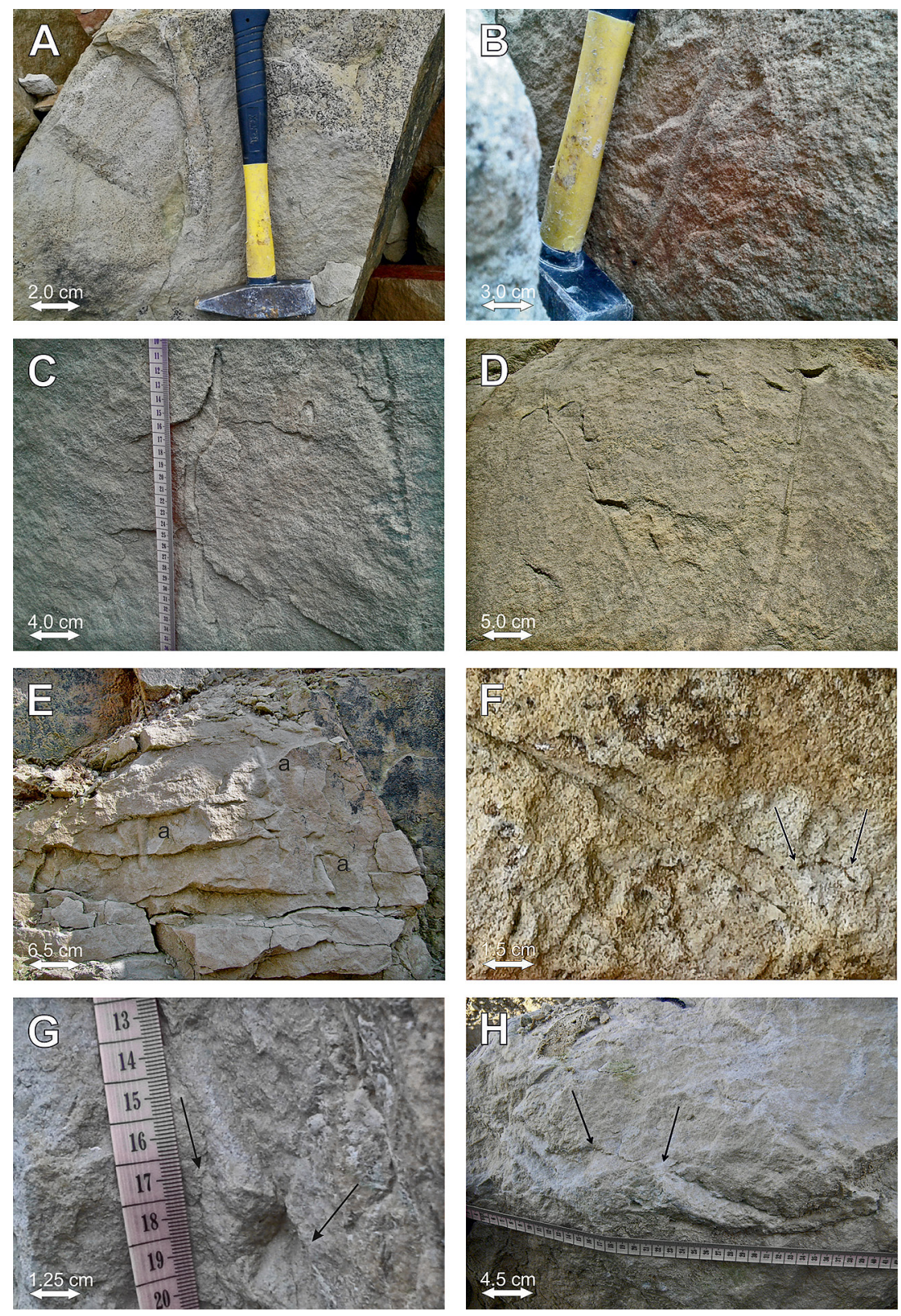

Fig. 6. Ophiomorpha. A, B - Ophiomorpha nodosa Lundgren, 1891, both Nowa Wieś Grodziska Quarry; C-E - Ophiomorpha isp., (C, D - Czaple Quarry; E - Nowa Wieś Grodziska Quarry); F-H Ophiomorpha nodosa Lundgren, 1891, swollen chambers, Nowa Wieś Grodziska Quarry. Arrows indicate swollen chambers of Ophiomorpha. and are now housed in collections of the Geological Museum of the University of Wrocław (MGUWr6623s-6624s).

Diagnosis: Ophiomorpha occurs as vertical, horizontal or inclined tunnels (isolated or creating boxwork). Burrow wall consisting predominantly of dense, irregular pellets, regularly distributed, very characteristic and diagnostic of this ichnogenus (after Frey et al., 1978).

Description: Specimens of Ophiomorpha nodosa studied appear mainly as single isolated shafts, vertical or subvertical or inclined, rarely horizontal with characteristic pelleted walls. In some cases an Ophiomorpha boxwork or Y-shaped branching pattern has been observed. The visible length of the burrows preserved on slab surfaces ranges from 4.0 to $40 \mathrm{~cm}$, while the diameter consistently is $0.3-1.5$ $\mathrm{cm}$, usually about $1.0 \mathrm{~cm}$. Burrow fill is structureless and the same as the host rock. Ophiomorpha is mostly elliptical, rarely circular in cross section. Some Ophiomorpha have swelling chambers (turnarounds), usually $2.0-3.0 \mathrm{~cm}$ (maximum $6.0 \mathrm{~cm}$ ) in width and up to $6.0 \mathrm{~cm}$ in length (Figs $5 \mathrm{H}, 6 \mathrm{~F}-\mathrm{H}$ ). One specimen shows a swelling at the end of the burrow (Figs 7D, 8). In some cases, burrow walls are poorly preserved, probably due to erosion, lacking well-developed pelleted lining. For this reason some specimens are indicated only at ichnogenus level (Ophiomorpha isp.) rather than O. nodosa (Fig. 6C-E).

Remarks: Ophiomorpha is interpreted as a domichnion or domichnion/fodinichnion, even agrichnion 

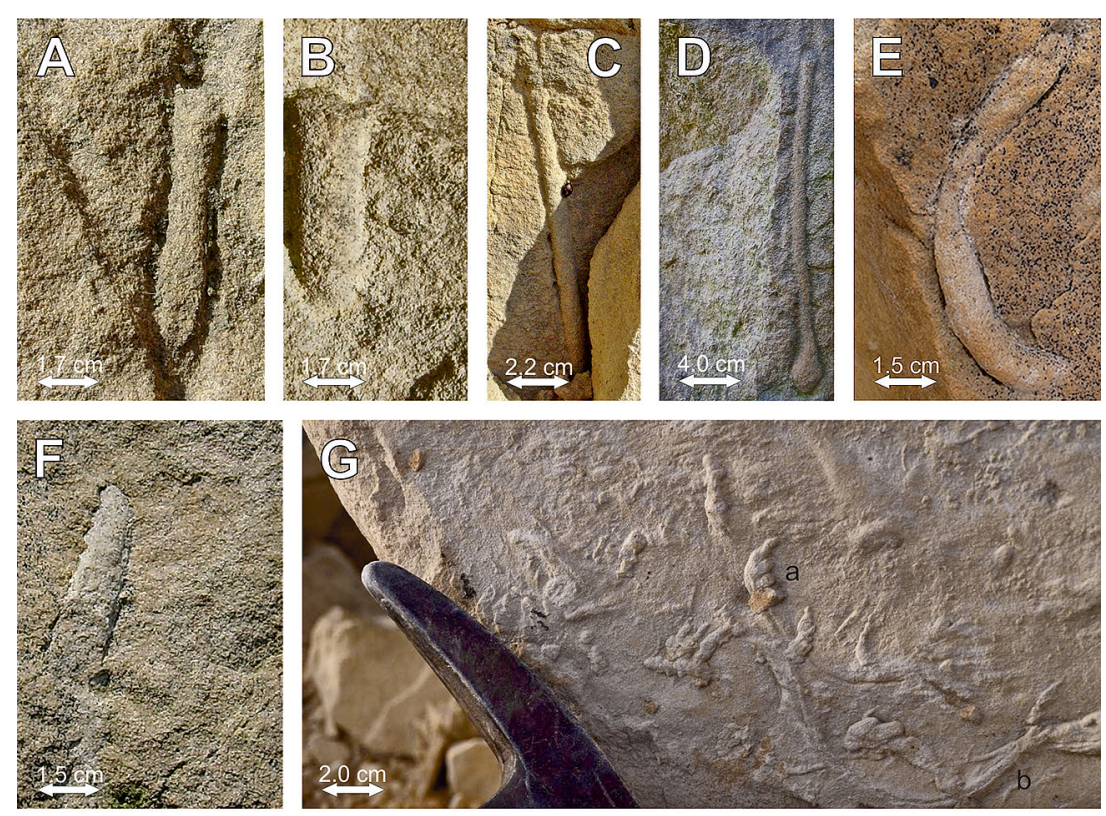

Fig. 7. Ophiomorpha, Phycodes and Planolites. A-F - Ophiomorpha nodosa Lundgren, 1891, (A-D - Czaple Quarry; E, F - Nowa Wieś Grodziska Quarry); G - Phycodes cf. curvipalmatum, Nowa Wieś Grodziska Quarry; $\mathrm{a}$ - arcuate ridge, $\mathrm{b}$ - branches; specimen found by A. Kowalski (photograph by A. Kowalski); H-I - Phycodes cf. flabellum (Miller and Dyer, 1878), Rakowice Małe Quarry; J - ?Phycodes isp., Nowa Wieś Grodziska Quarry; K - ?Phycodes isp. (a), Nowa Wieś Grodziska Quarry and Planolites cf. beverleyensis (Billings, 1862) (b). Arrows indicate trace fossils.
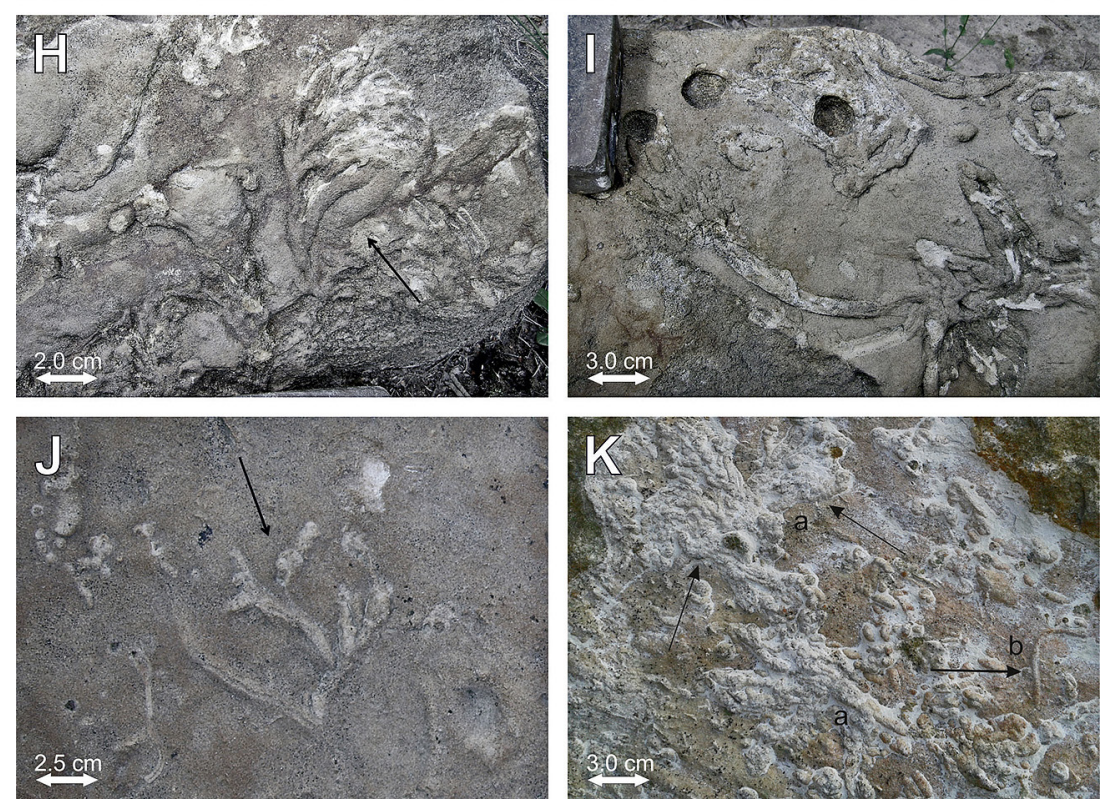

(Frey et al., 1978; Bromley, 1996; see also Uchman \& Gaździcki, 2006). The Ophiomorpha tracemakers are interpreted as deposit- and/or suspension-feeders to farmers (Bromley, 1996). Ophiomorpha is produced by decapod crustaceans, mainly callianassid shrimps; however, crayfish and crabs have also been considered as potential producers (Frey et al., 1978; Gibert et al., 2006). Modern analogues of possible tracemakers are Callichirus major (formerly Callianassa major), Protocallianassa, Axius and $\mathrm{Ne}$ otrypaea (Frey et al., 1978; Curran, 1984; Curran \& White, 1991; Savrda et al., 2010).

Ophiomorpha is most typical of the Skolithos and Cruziana ichnofacies (Frey \& Seilacher, 1980; MacEachern et al., 2007, 2012), being commonest under shallow-marine and marginal marine condi-

tions (Frey et al., 1978; Curran, 1985, 2007; Pollard et al., 1993; Goldring \& Pollard, 1995), although also occurring in offshore (Frey, 1990; Frey \& Howard, 1990), deep-sea (Uchman, 1991, 1992) and non-marine settings (Merill, 1984). It is most typical of the upper shoreface to upper offshore, although does appear in abundance in the upper-middle shoreface (Pemberton et al., 2001, 2012; Buatois \& Mángano, 2011). It is worth noting that Ophiomorpha nodosa prevails in shallow-marine settings (littoral and sublittoral; see Leaman et al., 2015, p. 39, fig. 2), whereas other ichnospecies such as O. rudis Książkiewicz, 1977 and O. annulata Książkiewicz, 1977 usually occur in deeper-water settings of the Nereites ichnofacies (see Tchoumatchenco \& Uchman, 2001; Uchman, 2009). 


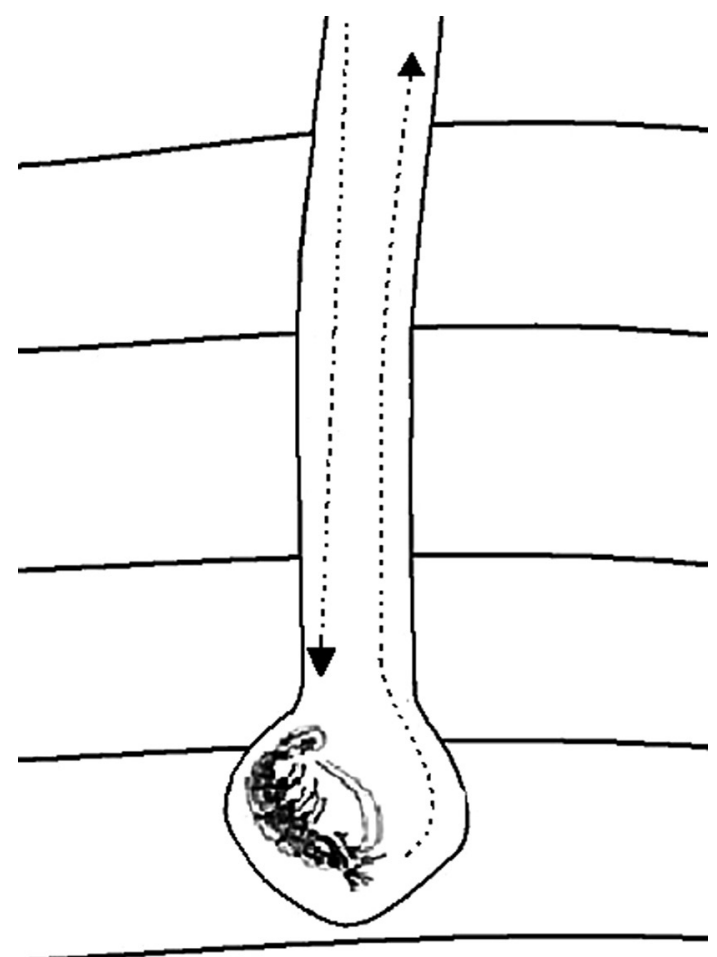

Fig. 8. Drawing of crustacean burrow with swollen chamber occurring at the end of the burrow (Fig. 7D).

This ichnogenus ranges from the Pennsylvanian (Anderson \& Droser, 1998) or Permian to Holocene (Frey et al., 1978; Buatois et al., 2016). Baucon et al. (2014) noted that Ophiomorpha in nearshore environments first appeared during the Permian.

\section{Phycodes cf. curvipalmatum (Pollard, 1981) \\ Fig. 7G}

Material: A few specimens preserved on sandstone slabs at the Nowa Wieś Grodziska Quarry.

Diagnosis: "Closely packed burrows, parallel at proximal end, then gently diverging to give a fasciculate appearance, or with oblique, closely spaced short branches; number of branches low, about 5" (after Jensen, 1997).

Description: Parallel, short, closely packed curved branches (3-4), 5-10 mm long, 3.5-4 mm wide. Burrows are horizontal, bending sharply upwards in distal portion. Some branches are strongly recurved. Burrow surface smooth or slightly wrinkled. A few, fragmentarily preserved arcuate ridges (up to several centimetres in length and 2-4 mm wide) with individual branches are visible.

Remarks: The specimens studied show similarities to Phycodes curvipalmatum described by Jensen (1997, fig. 51A, B), Desai et al. (2010) and Han \& Pickerill (1994, fig. 5/5) in having short, densely packed interwoven branches, which slightly curve upwards. According to Jensen (1997), Phycodes curvipalmatum differs from P. palmatus Hall, 1852 in having shorter, more curved branches.

Ethologically it is a fodinichnion produced by worm-like organisms (annelids) or pennatulacean and anthoptiloid sea pens (Häntzschel, 1975; Fillion \& Pickerill, 1990; Han \& Pickerill, 1994; Singh et al., 2008; references therein).

Phycodes is recorded mainly from shallow-marine environments characteristic of the Cruziana ichnofacies (Bromley, 1996; MacEachern et al., 2007). This ichnogenus usually occurs in lower shoreface/ upper offshore settings (Buatois \& Mángano, 2011), but may appear in shallower settings, e.g., upper to middle shoreface (Bjerstedt, 1987) and, less commonly, in deep-marine or even non-marine and brackish settings (Han \& Pickerill, 1994; Abbassi, 2007; Hubbard et al., 2012).

Its stratigraphical range is lower Cambrian to Palaeogene (Osgood, 1970; Chlupáč, 1997; Jensen \& Grant, 1998; Miller, 2001; Mángano \& Buatois, 2016; Shahkarami et al., 2017). Recently, Belaústegui \& Muñiz (2016) extended the range by describing Phycodes from Pliocene deposits in southwest Spain.

\section{Phycodes cf. flabellum (Miller \& Dyer, 1878)} Fig. $7 \mathrm{H}, \mathrm{I}$

Material: Several specimens, preserved as horizontal broom-like or flabellate bundles (convex hyporelief) found on sandstone slabs at the Rakowice Małe Quarry.

Diagnosis: "Phycodes flabellum has horizontally protrusive spreite fans, which are only on one side of a main shaft along which they may alternate between right and left" (after Osgood, 1970; see also Seilacher, 2000, p. 254, fig. 14).

Description: Phycodes cf. flabellum appears as a multibranched cylindrical or subcylindrical, horizontal burrow with thick rounded branches (creating a broom-like structure), originating from nearly the same point of a thick tunnel. Individual broomlike or flabellate sets comprise 5-7 burrows, which are straight or gently curved, semi-circular in cross section and distributed on one side of the main, straight ridge. In the studied specimens, branches are $0.5-0.7-1.0 \mathrm{~cm}$ wide and up to $6 \mathrm{~cm}$ long. The surface of the ridges is rather smooth. In some cases, burrow diameter in individual sets slightly increases distally. The diameter of the set usually is about $5.0 \mathrm{~cm}$ and a length of $8.5 \mathrm{~cm}$. On the surface of the sandstone at Rakowice Małe Quarry, typically unconnected sets occur (Fig. 7I). The burrow fill is similar in lithology to the host rock.

Remarks: Specimens studied (Fig. 7H, I) show some similarities to Phycodes flabellum as described by Seilacher (2000, p. 254, fig. 14) and to Phycodes 
cf. flabellum recorded by Stachacz (2016, p. 307, fig. $14 \mathrm{C})$, especially in having branching ridges situated along the main stick, on one side (right) only. Material studied also resembles Phycodes flabellum as recorded by Bjerstedt \& Erickson (1989, pp. 221223, fig. 14D-F), especially the specimen illustrated in their fig. 14E (branches are distributed on right side of the main channel and are slightly winding). Some similarities also exist to Phycodes flabellum of Aceñolaza et al. (2010, pp. 166-167, fig. 3), but the surface of the studied burrow is not so distinctly ornamented. Another difference is the lack in our material of any alternation of ridges between right and left, along one side of main tunnel. The specimen illustrated in fig. 9A in Rindsberg \& Martin (2003) is closely similar to material from the Czaple Quarry, but another one (their fig. 9B) possesses longer and ornamented branches. In comparison to Phycodes palmatus Hall, 1852, as described by Han \& Pickerill (1994, p. 43, fig. 5/12), Chlupáč (1997, fig. 5/6), Jensen \& Grant (1998, fig. 6/a), Singh et al. (2008, fig. 4/b, c) and Stachacz (2016, p. 307, fig. 14D), our material does not show branches diverging from the same point, creating a palmate structure. They differ also from Phycodes cf. palmatus as recorded by El-Hedeny et al. (2012, p. 727, fig. 5C, D) by having more branches in individual broom-like sets and are quite different from Phycodes templus Han and Pickerill, 1994 (p. 3, fig. 2), due to a lack of a pagoda-like structure, which consists of several interconnected broom-like bundles.

\section{Phycodes Richter, 1850}

\section{?Phycodes isp.}

Fig. 7J, K

Material: A single specimen preserved in full relief on a sandstone block (Fig. 7J) at the Nowa Wieś Grodziska Quarry. Numerous specimens visible on surfaces of sandstone, co-occurring with Planolites cf. beverleyensis Billings, 1862 (Fig. 7K) at the same quarry.

Description: Phycodes appears as a broom-like burrow, occurring as a bundle of tubes originating likely from the same point of a single stem. Horizontal tubes usually consist of few branches (usually 5-6). The diameter and length of the whole structure is 9.0 and $7.0 \mathrm{~cm}$, respectively, whereas individual burrows in the set are $0.5-0.7 \mathrm{~cm}$ wide (Fig. 7J). The specimens that co-occur with Planolites cf. beverleyensis (Fig. 7K) are $5 \mathrm{~cm}$ wide and $6 \mathrm{~cm}$ long and consist of 5-6 branches in individual sets.

Remarks: These structures do not differ from other specimens assigned to the ichnogenus Phycodes (for a discussion of the ichnogenus see Osgood, 1970, Fillion \& Pickerill, 1990; Han \& Pickerill, 1994). The state of preservation is not good and does not allow ichnospecific identification. The studied specimen (Fig. 7J) shows some similarities to Phycodes isp. described by Zhang \& Zhao (2015, p. 335, fig. 6a) in having arc-shaped branches diverging nearly from the same point. However, it differs in having another structural pattern (not flabellate) and a smaller number of branches. It also differs from Phycodes palmatus Hall, 1852 in the lack of a palmate structure (compare Han \& Pickerill, 1994, p. 43, fig. 5.12). The present specimen does not show branches situated on one side of the main stick, as in Phycodes flabellum (see Stachacz, 2016, p. 254, fig. 14C). It differs also from $P$. circinatus Richter, 1853 in having a smaller number of larger ridges (smaller and closely spaced, parallel to one another, see Stachacz, 2016, pp. 305-307, fig. 14A, B). Numerous specimens on sandstone slabs (Fig. 7K) resemble mainly Phycodes isp. as recorded by Zhang \& Zhao (2015, fig. 6a) in having straight or slightly winding 5-6 branches in broom-like sets that are not arranged on one side of main stick (i.e., not as in Phycodes flabellum).

\section{Planolites Nicholson, 1873}

\section{Planolites cf. beverleyensis Billings, 1862}

Fig. 7K

Material: A single specimen preserved on the surface of a sandstone block at Nowa Wieś Grodziska Quarry.

Diagnosis: Straight or slightly curved, horizontal semi-circular or semi-elliptical cylindrical ridges with smooth surface (without lining), which are infilled by material that differs slightly in colour from the host rock (after Stachacz, 2012, 2016; see also Pemberton \& Frey, 1982).

Description: Planolites occurs as slightly curved, horizontal, unbranched meandering burrows (unornamented, unlined, cylindrical), elliptical in cross section, with a visible length of up to $6.0 \mathrm{~cm}$ and a diameter of $0.3 \mathrm{~cm}$, on the bedding plane.

Remarks: This specimen does not differ from Planolites beverleyensis as described by Shi et al. (2015, figs. 3J, 4E), Stachacz (2016, p. 302, fig. 12C) and Rodríguez-Tovar et al. (2014, p. 550, fig. 7E). In comparison to Planolites montanus Richter, 1937, the present specimen does not plunge into the bed, which is characteristic of this ichnospecies (compare Rodríguez-Tovar et al., 2014, fig. 7G) and Stachacz (2012, p. 111, fig. 6A; 2016, p. 302, fig. 12D).

It is interpreted as a pascichnion of deposit feeders, mostly polychaetes (Pemberton \& Frey, 1982; 
Keighley \& Pickerill, 1995), but may also have been produced by bivalves (see Knaust, 2007) or insect larvae in non-marine settings (Gradziński \& Uchman, 1994; Kim et al., 2002).

It is a facies-crossing, eurybathic form, but most commonly has been recorded from shallow-marine environments of the Cruziana ichnofacies (Buatois \& Mángano, 2011; Pemberton et al., 2001, 2012).

This taxon is known from the Proterozoic to Holocene (Häntzschel, 1975; McCann \& Pickerill, 1988; Mángano \& Buatois, 2016).

\section{Thalassinoides Ehrenberg, 1944}

\section{Thalassinoides paradoxicus Woodward, 1830}

Fig. 10A

Material: A single specimen preserved on a sandstone quarry face at Czaple.

Diagnosis: Irregularly branched, subcylindrical to cylindrical burrows oriented at various angles with respect to bedding; T-shaped branches are commoner than Y-shaped bifurcations (after Howard \& Frey, 1984, p. 213).

Description: Thalassinoides paradoxicus appears as a horizontal or inclined, cylindrical, unlined burrow. At the end of the burrow, T-shaped, rather than Y-shaped, branching is visible (Fig. 10A). The burrow fill is the same as the host rock. The diameter varies from 2.0 to $3.0 \mathrm{~cm}$. The visible length is $>60$ $\mathrm{cm}$.

Remarks: The variable diameter and irregular pattern of branching suggests assignment to T. paradoxicus. The burrow studied does not differ from specimens described by Tiwari et al. (2011, p. 1139, fig. 4e).

Thalassinoides is interpreted as domichnia/fodinichnia/agrichnia of deposit feeders (Myrow, 1995; Bromley, 1996; Ekdale \& Bromley, 2003). Thalassinoid shrimps (ghost shrimps), lobsters, crayfish and crabs, as well as fish, cerianthid sea anemones and balanoglossan enteropneusts have been suggested as potential tracemakers (Frey et al., 1984; Myrow, 1995; Ekdale \& Bromley, 2003; Chen et al., 2011). In non-marine settings, crayfish may be producers of Thalassinoides (Kim \& Kim, 2002; Yanin \& Baraboshkin, 2013). Possible producers (living or extinct crustacean genera; see Stamhuis \& Videler, 1998; De Grave et al., 2009) include Callianassa, Mecochirus, Meyeria and Glyphea (Neto de Carvalho et al., 2007; Hembree et al., 2011; Neto de Carvalho, 2016).

This eurybathic ichnotaxon occurs in different ichnofacies (MacEachern et al., 2007, 2012), even in deep-sea settings (Uchman, 1991, 1998). It is commonest in shallow-marine settings of the Cruziana ichnofacies (from upper to distal lower shoreface), although its environmental distribution ranges from marginal marine to offshore (RodríguezTovar et al., 2008; Leszczyński, 2010; Pemberton et al., 2012).

This ichnogenus is known from the Cambrian (Fortunian) to Recent (Mikuláš, 2000; Sprechmann et al., 2004; Zhang et al., 2017), being common from Ordovician onwards (Sheehan \& Schiefelbein, 1984; Jin et al., 2011; Mángano et al., 2016).

\section{?Thalassinoides isp.}

Fig. 10B

Material: A single isolated specimen, fragmentarily preserved on a sandstone slab at Nowa Wieś Grodziska Quarry, now housed in the collections of the Geological Museum of the University of Wrocław (MGUWr-6625s).

Description: ?Thalassinoides isp. appears as a cylindrical, unlined, flattened tunnel (probably part of a larger burrow), gently curved, elliptical in cross section, with a diameter from 2.0 to $4.5 \mathrm{~cm}$, usually $2.5 \mathrm{~cm}$ and a length of $15 \mathrm{~cm}$.

Remarks: This specimen possesses a characteristically flattened shape of Thalassinoides and a slightly curved course. This ichnotaxon might probably have exhibited a Y-shaped branching pattern, typical of Thalassinoides suevicus Rieth, 1932 (e.g., Uchman \& Tchoumatchenco, 2003, p. 31, fig. 8). Due to the lack of branching, it is here listed in open nomenclature.

\section{Thalassinoides-Phycodes compound burrow systems}

\section{Thalassinoides-Phycodes cf. palmatus}

Figs 4D, 9A

Material: This composite trace fossil (a compound burrow system of Thalassinoides-Phycodes cf. palmatus and Gyrochorte) occurs on a sandstone surface, covering well-preserved wave ripple marks (Figs 4D, 9A) at Nowa Wieś Grodziska Quarry (Fig. 2; quarry 1).

Description: This compound burrow system consists of horizontal, branching tunnels of Thalassinoides and Phycodes cf. palmatus, usually occurring at end end of branches. In some cases, isolated burrows, especially of Phycodes cf. palmatus, appear on sandstone surfaces (probably reflecting state of preservation). Thalassinoides, which forms the core of these compound structures, appears as straight or slightly undulose horizontal tunnels with branches under acute angles; parallel to bedding plane. Vertical tunnels were not noted. Diameter of tunnels 


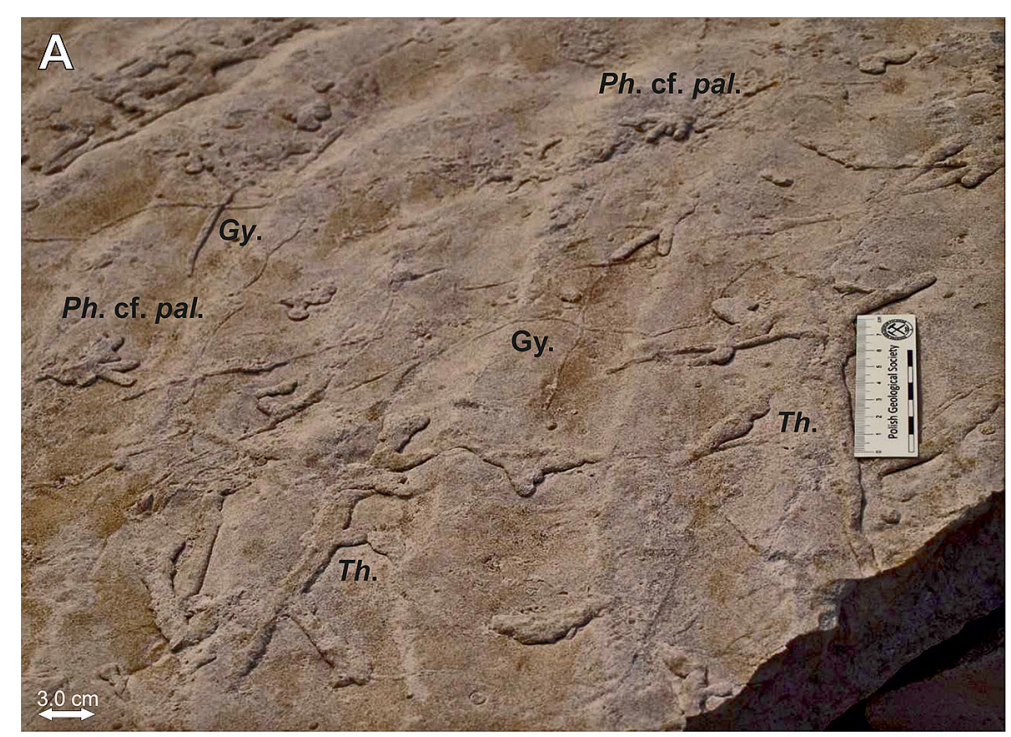

Fig. 9. Thalassinoides-Phycodes compound burrow systems. A - Thalassinoides-Phycodes cf. palmatus, Th. - Thalassinoides, Ph. cf. pal. - Phycodes cf. palmatus, Gy. - Gyrochorte; Nowa Wieś Grodziska Quarry; B - ?Thalassinoides-Phycodes, Czaple Quarry, ?Th. - ?Thalassinoides, ?Ph. - ?Phycodes. Both specimens found by A. Kowalski, photographs by A. Kowalski. Arrows indicate?Phycodes.

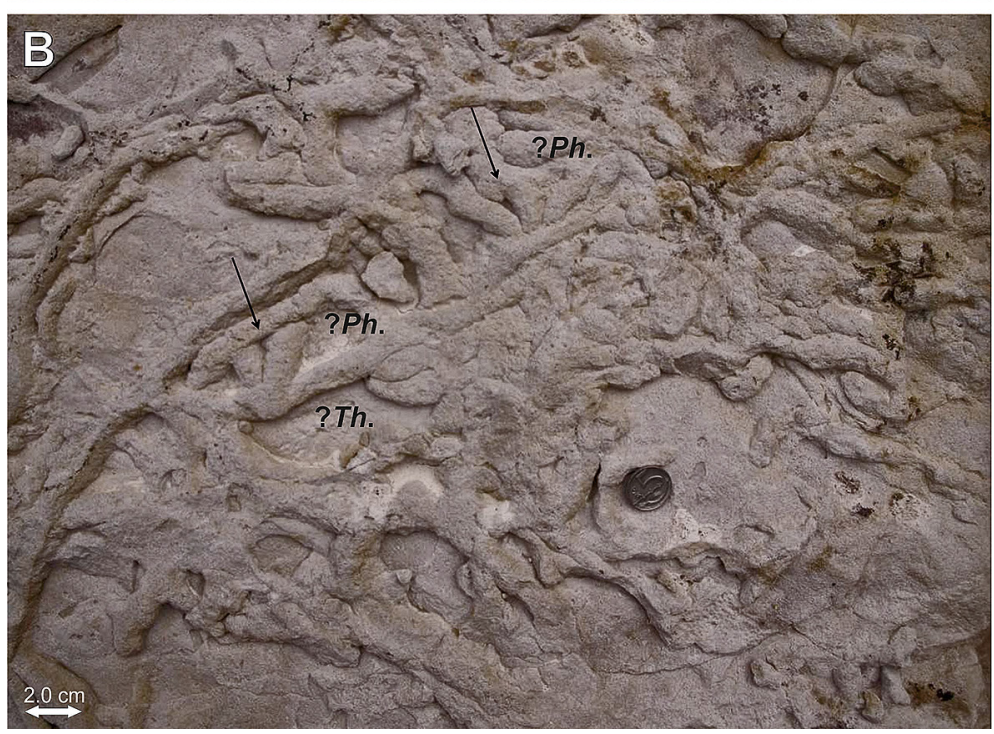

studied varies from 1.0 to $2.5 \mathrm{~cm}$, the visible length being up to $20 \mathrm{~cm}$. Phycodes occurs at distal margins, usually at the end of branches. Up to six individual branches in individual sets are observed (Fig. 9A), which create palmate-like or fan-shaped structures resembling P. palmatus. The diameter of these branches is about $0.7 \mathrm{~cm}$, the length of the whole set being $6.0 \mathrm{~cm}$. The Thalassinoides-Phycodes compound trace fossil co-occurs with Gyrochorte, which probably appeared first (Fig. 9A).

Remarks: These specimens resemble the compound burrow system described by Miller (2001, p. 153, fig. 7), in which "one ichnotaxon passes gradually or directly into another" (compare Pickerill, 1994). They usually are interpreted as dwelling-feeding structures produced by crustaceans (see Miller, 2001). Such burrow systems probably were inhabited by tracemakers for a relatively long period and had more than one function (see Miller, 1998, 2001).
In the studied compound burrow systems the tunnels of Thalassinoides probably were used as domichnia (runways, protected areas), while Phycodes might have been created as food-mining structures (compare Miller, 2001), probably in food-rich zones. Miller (2001) also suggested another possibe ethological behaviour for Thalassinoides-Phycodes tracemakers, such as e.g., cultivation of bacteria, ventilation of burrow systems and protecting/brooding juveniles. The present specimens (Phycodes cf. palmatus), which show a characteristic palmate structure, do not differ from specimens described as Phycodes palmatus by Chlupáč (1997, pl. 3, figs. 1, 3, 6), Jensen (1997, figs. 50, 51B), Knaust (2004, fig. 7.3), Singh et al. (2008, fig. 4b, c), Desai et al. (2010, fig. 3I) and Stachacz (2016, fig. 14D). It is also most similar to Phycodes palmatus as described by Hanken et al. (2016, fig. 10B). These burrows are typical of the Cruziana ichnofacies. Compound burrow systems have 

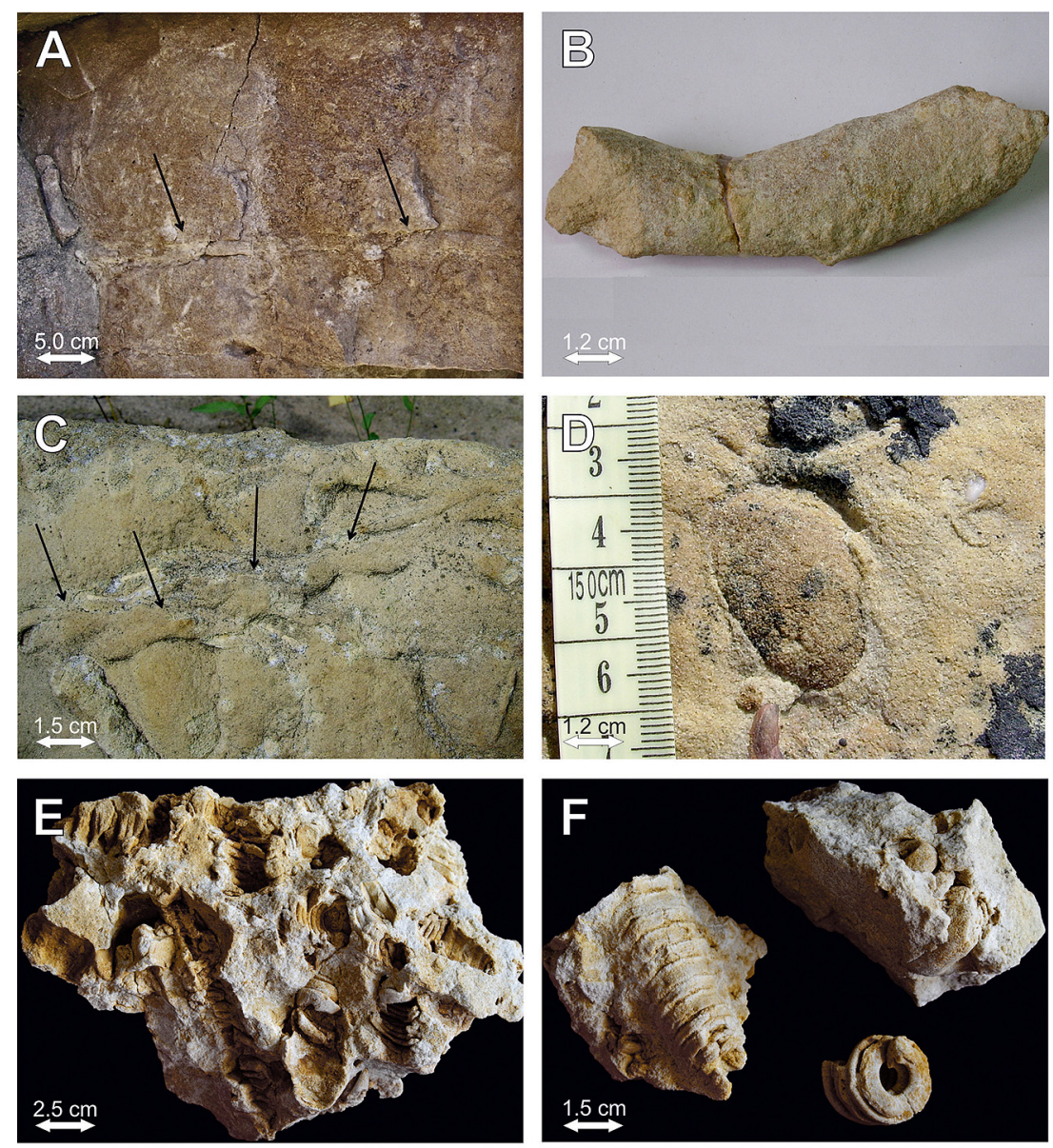

Fig. 10. Thalassinoides and body fossils (bivalves, gastropods). A - Thalassinoides paradoxicus Woodward, 1830 (Czaple Quarry); B - ?Thalassinoides isp. (Nowa Wieś Grodziska Quarry; MGUWr-6625s); C - ?Treptichnus isp. (Rakowice Małe Quarry); D - Lima haidingeri Zittel, 1866 (Nowa Wieś Grodziska Quarry; MGUWr-6626s); E, F - Nerinea bicincta Bronn, 1836 (Czaple and Nowa Wieś Grodziska quarries; MGUWR-6627-MGUWr-6631s); G - Nerinea buchi Zekeli, 1852 (collected by Drescher in 1867), Coniacian at Żeliszów Quarry (formerly Giersdorf; MGUWr-1592s); H - Cyrena cretacea Drescher, 1863 (collected by Drescher) (MGUWr-1542s), Santonian at Rakowice Małe Quarry (formerly Wenig-Rackwitz).

usually been recorded from deep-sea settings, e.g., the deeper part of the offshore shelf (Miller, 2001; Abbassi et al., 2015). However, the Phycodes-Rusophycus association was found by Zhang \& Zhao (2015) in the low-energy zone of the upper shoreface.

\section{?Thalassinoides-Phycodes}

Fig. 9B

Material: Numerous specimens preserved on sandstone slabs at Czaple Quarry (Fig. 2; quarry 4).

Description: This compound trace fossil (Fig. 9B) occurs as horizontal, straight or more commonly slightly curving tunnels. It seems that the main tunnels (?Thalassinoides) have two or three branches, which originated from nearly the same point. These branches are arranged on one side of the main tun- nels and form "palmate-like" structures, which resemble Phycodes (Fig. 9B). The dimension of the main tunnels and branches is similar, between 15 and $20 \mathrm{~mm}$, their visible length being up to several centimetres. Due to the poor state of preservation, the studied specimens are referred to as ?Thalassinoides-Phycodes.

\section{Treptichnus Miller, 1889}

\section{?Treptichnus isp.}

Fig. 10C

Material: A single specimen, consisting of six segments and some specimens that comprise of two or three isolated, joined segments, fragmentarily 
preserved on a sandstone block at Rakowice Małe Quarry.

Description: Six segments, connected at their end (joined to each other), are visible on the sandstone surface, oriented under an oblique angle, to the main axis of the trace. The length of the whole structure is about $12 \mathrm{~cm}$, segments are up to $2 \mathrm{~cm}$ long and $0.5-0.7 \mathrm{~cm}$ wide, preserved in hyporelief.

Remarks: This specimen is similar to Treptichnus as described by Singh et al. (2017, fig. 9d) and Jensen (1997, fig. 62B), as "burrows consisting of segments connected at their ends, each to the next one, but not in a zigzag pattern" (compare Singh et al., 2017). It does not differ significantly from specimens recorded by Hofmann et al. (2012, fig. 9/2), Srivastava (2012, fig. 3A, B), Buatois et al. (2013, fig. 1A) and Stachacz (2016, fig. 14E) either. However, due to the poor state of preservation it is difficult to say if individual segments plunged into the bed or not (compare Stachacz, 2016).

Treptichnus is interpreted as a fodinichnion or agrichnion produced by vermiform animals (wormlike animals) or insect larvae (Buatois \& Mángano, 1993; Schlirf, 2003; Stachacz, 2016; references therein).

Schlirf (2003) recorded Treptichnus from the foreshore-upper shoreface, while Singh et al. (2017) noted examples from the shoreface. Buatois et al. (2013) and Buatois (2018) suggested a broad environmental tolerance of the tracemakers of Treptichnus, which can occur both in deep and shallow settings. It is known from the Ediacaran to Recent (Jackson et al., 2016; Mángano \& Buatois, 2016).

\subsection{Associated body fossils}

In addition to trace fossils, associated body fossils (bivalves, gastropods) were also collected. The most interesting is the gastropod Nerinea bicincta Bronn, 1836 (Fig. 10E, F; MGUWr-6627s-6631s), which was previously recorded from the Coniacian at Żeliszów Quarry (formerly Giersdorf) by Scupin (1912-1913, pp. 118-120, pl. 4, fig. 1; pl. 5, fig. 17). The present specimens are up to $6.0-7.0 \mathrm{~cm}$ long and measure 1.0 to $2.8 \mathrm{~cm}$ in width. In the collections of the Geological Museum of the University of Wrocław there is a specimen described as Nerinea buchii Zekeli, 1852 (now Nerinea bicincta, see synonymy in Lommel, 184; Scupin, 1912-1913), which was collected at Żeliszów Quarry (Giersdorf) in 1867 by Drescher (Fig. 10G). Andert (1934) recorded Nerinea bicincta (without illustrations) from the Coniacian of Lower Silesia, from Żeliszów Quarry (formerly Giesdorf), Bielawa Dolna Quarry (formerly Niderbielau) and from Saxony and Austria. Nerinea bicincta was also recovered from Upper Cretaceous levels in Austria and Romania by Klinghardt (1944) and Földvary (1988).

The limid bivalve Lima haidingeri Zittel, 1866 (Fig. 10D; MGUWr-6626s), which also occurs in these blocks, were previously recorded from the Coniacian of the North Sudetic Synclinorium (Żeliszów Quarry [formerly Giersdorf], Rakowice Małe Quarry [formerly Wenig-Rackwitz] and Żerkowice Quarry [formerly Sirgwitz], see Fig. 1) by Scupin (1912-1913, pp. 231-232, pl. 13, fig. 9; pl. 14, fig. 1; text-figs. 42, 43). Andert (1934) cited Lima haidingeri from the same quarries as above, from the Coniacian at Żeliszów Quarry and from the Upper Cretaceous of Rakowice Małe and Żerkowice and Austria. ?Lima haidingeri has also been described from the Coniacian at Jerzmanice Zdrój (North Sudetic Synclinorium; Chrząstek, 2008).

Additionally, the bivalve Cyrena cretacea Drescher, 1863 is represented in the collections of the Geological Museum of the University of Wrocław (MGUWr-1542s; Fig. 10H). These bivalves, typical of mesohaline conditions, were found by Drescher at Rakowice Małe Quarry (formerly Wenig-Rackwitz) in the Upper Cretaceous. Scupin (1912-1913), Alexandrowicz (1976) and Milewicz (1988) also recorded this species from the Santonian of the North Sudetic Synclinorium.

\section{Palaeoenvironment of Coniacian sandstones}

The low-diversity trace fossil assemblage (six ichnogenera, eleven ichnospecies and two compound burrow systems) allows to add some data towards the palaeoenvironmental interpretation of Coniacian sandstones (Żerkowice Member) by Leszczyński (2010). The trace fossil assemblage at the Czaple-Nowa Wieś Grodziska quarries is typical of shallow-marine settings and characterises the Skolithos and Cruziana ichnofacies. It is dominated by pascichnia (Planolites, Gyrochorte), fodinichnia/ agrichnia/domichnia (Thalassinoides), fodinichnia (Phycodes) or domichnia (Ophiomorpha) produced by deposit- and suspension-feeders or predators.

Abundant Gyrochorte is considered to be indicative of nearshore, shallow-marine settings (Gibert \& Benner, 2002). It usually occurs in storm-influenced, lower shoreface/upper offshore settings (Pemberton et al., 2001, 2012; Seidler \& Steel, 2001; Buatois \& Mángano, 2011, 2013; Bressan et al., 2013) up to the upper to middle shoreface (Mieras et al., 
1993; Pearson et al., 2013; Bayet-Goll et al., 2015). The tracemaker has been suggested to be an opportunistic organism (post-event) that used to colonise the sandy substrate during quiet energy conditions (fair-weather), after high-energy storm events (see Gibert \& Benner, 2002; Joseph et al., 2012). Gyrochorte usually is associated with other pascichnia or fodinichnia. At the Czaple quarries, this ichnotaxon co-occurs with Planolites and Phycodes. According to Han \& Pickerill (1994) and Neto de Carvalho et al. (2016), Gyrochorte often is associated with Thalassinoides and Ophiomorpha in the post-Middle Jurassic Mesozoic deposits.

Phycodes mainly occurs in low-energy, shallow-marine settings (Han \& Pickerill, 1994). It is common in storm-dominated shelf deposits (Pickerill et al., 1995) and usually appears from the upper to the lower shoreface (Mayoral et al., 2013). Hanken et al. (2016) recorded Phycodes mainly from the upper-middle shoreface. The second ichnotaxon, Planolites, is a eurybathic, facies-crossing burrow, but it appears in abundance in shallow-marine settings (Pemberton et al., 2012; Baucon \& Neto de Carvalho, 2016). Frey \& Dashtgard (2011) reported Planolites from the upper/middle shoreface.

Ophiomorpha is the most abundant trace fossil at the quarries studied. On account of the common occurrence of Ophiomorpha in nearshore settings (high-energy, shallow- and marginal marine) is considered a palaeobathymetric indicator (Frey et al., 1978; Curran \& White, 1991; Miller \& Curran, 2001; Pemberton et al., 2001). According to Pemberton et al. (2012), Ophiomorpha nodosa usually appears from the foreshore to offshore (e.g., Curran, 1985), but is most abundant in the foreshore-upper shoreface-middle shoreface (Pollard et al., 1993; Howell et al., 1996; Malpas et al., 2005), while others such as Ophiomorpha rudis or O. annulata are typical of deeper settings (see Uchman \& Demircan, 1999; Tchoumatchenco \& Uchman, 2001; Uchman, 2009; Nagy et al., 2016).

Less common at the Czaple-Nowa Wieś Grodziska quarries are ?Thalassinoides isp. or T. paradoxicus. This ichnogenus, where it appears in abundance, is most typical of the distal lower shoreface (see ichnological-sedimentological models by Pemberton et al., 2001, 2012). Several authors have typified such environments as the most characteristic of Thalassinoides (Uchman \& Krenmayr, 2004; Pervesler et al., 2011; Chrząstek, 2013b; Mayoral et al., 2013). On the other hand, single occurrence of Thalassinoides can be observed also in upper shoreface-middle shoreface settings (Hampson \& Storms, 2003; Malpas et al., 2005; Leszczyński, 2010; Buatois \& Mángano, 2011; Bayet-Goll et al., 2015). The presence of this ichnotaxon usually suggests good oxygenation and low-energy conditions (Buatois \& Mángano, 2011).

The occurrence of Thalassinoides-Phycodes cf. palmatus and ?Thalassinoides-Phycodes compound burrow systems might also suggest the presence of low-energy episodes (see Miller, 2001). Although such burrow systems have usually been noted from open-marine, low-energy, deeper settings, e.g., offshore (Patel et al., 2009; Abbassi et al., 2015), abundant Phycodes co-occurring with Rusophycus was described from the upper shoreface by Zhang \& Zhao (2015). It is worth noting that in the present example, the compound burrow system Thalassinoides-Phycodes cf. palmatus is preserved on top of wave ripple marks, suggesting deposition of these sandstones above fair-weather wave base. Additionally, the presence of burrows left by deposit feeders, especially Thalassinoides-Phycodes compound burrows, might suggest the occasional availability of sufficient organic matter in these deposits (see also Patel et al., 2009). According to Rodríguez-Tovar et al. (2017; references therein), horizontally extended burrow systems (e.g., Thalassinoides) without vertical shafts, might indicate favourable environmental conditions (enough food on sea floor and within the uppermost part of the deposit) and exploitation of the sediment by deposit feeders (fodinichnia). On the other hand, those authors recorded that this kind of burrow (horizontal system) might have been produced in order to "maximalize the capture of organic matter, when the substratum has a low nutritional value" (see also Suchanek et al., 1986) or when substrate consistency in the upper part of the deposit is inappropriate (e.g., less cohesive) for tracemakers to produce vertical shafts.

At all quarries, throughout the section, Ophiomorpha is present, whereas Thalassinoides, Phycodes, Gyrochorte and Planolites appears in the bottom and upper parts (Fig. 3). Vertical, subvertical and inclined burrows of Ophiomorpha might suggest higher-energy conditions, whereas the presence of horizontal burrows (Gyrochorte, Ophiomorpha, Phycodes, Planolites), as well as compound burrow systems (Thalassinoides-Phycodes) suggest lower hydrodynamic conditions (see also Frey et al., 1978; Anderson \& Droser, 1998).

The present study is in agreement with sedimentological interpretations of the sandstones of the Żerkowice Member by Leszczyński (2010). That author considered Coniacian sandstones at Rakowice Małe and Żerkowice quarries to be bar and storm deposits, laid down mainly from the foreshore to upper shoreface (up to the middle shoreface). Based on the presence of large-scale cross-stratification (onshore- and offshore-directed), Leszczyński 
(2010) suggested that the deposition of these sandstones (Żerkowice Member) occurred in a palaeonvironment of high hydrodynamics, occasionally during storm events (see Leszczyński, 2010; references therein). The present study seems to support this view. The presence of a trace fossil assemblage typical of shallow-marine settings, trough cross bedding, wave ripples, planar lamination, as well as a lack of hummocky cross-stratification (HCS) suggest deposition above fair-weather wave base, probably from the upper shoreface to middle shoreface (see Dott \& Bourgeois, 1982; Duke, 1985; Hampson \& Storms, 2003; Leszczyński, 2010; Joseph \& Patel, 2015; see Fig. 4).

In comparison with previous work by Leszczyński (2010), the present study shows that Coniacian sandstones at the Czaple-Nowa Wieś Grodziska quarries might have been laid down in an environment similar to that at Żerkowice Quarry (up to the middle shoreface; see Leszczyński, 2010). This is confirmed by the higher ichnotaxonomic diversification in comparison to Rakowice Małe Quarry, from where only Thalassinoides and Ophiomorpha were recorded, plus the occurrence of numerous horizontal structures (Phycodes, Planolites, Thalassinoides, Gyrochorte, Thalassinoides-Phycodes).

Callianassid crustaceans - the possible tracemakers of Ophiomorpha and Thalassinoides - inhabit mainly shallow waters, especially up to $200 \mathrm{~m}$ (see Weimer \& Hoyt, 1964; Griffis \& Suchanek, 1991; Dworschak 2000; Leaman et al., 2015). They prefer waters with normal salinity, although tolerate fluctuations (Frey et al., 1978; Swinbanks \& Luternauer, 1987). The blocks with gastropods (Nerinea bicincta) and bivalves (Lima haidingeri) also point to a well-oxygenated palaeoenvironment.

According to Sohl \& Kollmann (1985), Nerinea bicincta, which occurred along the northern margin of Tethys in Poland and the Czech Republic, probably had warm-water affinities. Sanders (1998) recorded that large-sized nerineids usually occurred in shallow subtidal, open lagoonal environments. Wieczorek (1979) and Cataldo (2013; references therein) suggested that nerineoids appeared in abundance in benthic assemblages of Jurassic and Cretaceous carbonate ramps and platform environments, being typical of subtropical to tropical marine conditions of the Tethys Ocean. In summary, nerineids are considered to be indicative of warm, tropical conditions of the Tethyan Realm (see Sohl, 1987; Saul \& Squires, 1998). They usually appear in euryhaline and mesohaline waters (Sohl \& Kollmann, 1985) in shallow environments with moderate levels of energy.

A similar assemblage of trace fossils, typical of shallow-marine environments (shoreface), were de- scribed by Singh et al. (2008), Paranjape et al. (2014) and Bayet-Goll et al. (2015).

In summary, both ichnological analysis and the presence of bivalves and gastropods point to a well-oxygenated, shallow-marine environment, probably foreshore-middle shoreface.

\section{Palaeogeography}

During the Late Cretaceous, in the North Sudetic Basin appeared a mixed fauna typical of both warmer and colder seas, e.g., Tethys Ocean and North Sea (see also Chrząstek \& Wojewoda, 2011). The occurrence of the gastropod Nerinea bicincta, typical of tropical conditions (Sohl, 1987; Saul \& Squires, 1998) in Coniacian sandstones (Żeliszów Quarry) supports this view (see also Scupin, 19121913). The North Sudetic Basin was a narrow seaway between the so-called East Sudetic Island during the early Turonian (Biernacka \& Józefiak, 2009) and the Karkonosze-Izera and Orlica-Bystrzyca highs (Chrząstek \& Wojewoda, 2011; see also Sudetic islands after Voigt et al., 2008; Olde et al., 2016; Košt'ák et al., in press). The North Sudetic Basin linked the shelf sea of central Europe to that of the Bohemian Cretaceous Basin (Biernacka \& Józefiak, 2009). The study of Coniacian flora, originating from the East and West Sudetic islands and studied by Halamski \& Kvaček $(2015,2016)$ and Kvaček et al. (2015), also hinted at a warm, subtropical climate during the Late Cretaceous in the Sudetes. The finds of tree ferns in the vicinity of Żeliszów and Lwówek also supports this view (Greguš et al., 2013).

According to Milewicz $(1997,1998)$, the wide areal extent of Coniacian sandstones (widest during the early Coniacian) may be connected with a gradual upward movement of the sea floor from the east (probably during the Subhercynian phase of the Alpine orogeny, sensu Stille, 1924; see also Voigt et al., 2004). Sandy deposits prevail in the southeast, whereas marls occur on the northwestern margins of the North Sudetic Synclinorium (see Milewicz, 1979).

At the end of the early Santonian, the sea withdrew from northern Bohemia, Saxony and Lower Silesia. Earlier deposition of Santonian sands, sandstones, mudstones and clays, with coal layers and kaoline, occurred in bays separated by barriers from the open sea, due to regression. Mesohaline conditions at the time is confirmed by the presence of Cyrena cretacea (MGUWr-1542s; Fig. 10H) in the Santonian at Rakowice Małe Quarry (see also Scupin, 1912-1913; Alexandrowicz, 1976; Milewicz, 1988). 


\section{Summary and conclusions}

In Coniacian quartz sandstones (Żerkowice Member, Rakowice Wielkie Formation) at the Czaple-Nowa Wieś Grodziska and Rakowice Małe quarries (North Sudetic Synclinorium, southwest Poland) a low-diversity assemblage of trace fossils, comprising six ichnogenera, eleven ichnospecies and two compound burrow systems, was identified. Some of these, especially Gyrochorte isp., ?Gyrochorte isp., Phycodes cf. curvipalmatum, Phycodes cf. flabellum, ?Phycodes, Planolites cf. beverleyensis, ?Treptichnus and Thalassinoides-Phycodes cf. palmatus and ?Thalassinoides-Phycodes burrow systems have not been recorded previously from these deposits. Some bivalve and gastropod species were also reported.

Ethologically these trace fossils represent domichnia (Ophiomorpha), domichnia/fodinichnia/agrichnia (Thalassinoides), pascichnia (Gyrochorte, Planolites) and fodinichnia (Phycodes). The compound burrow systems Thalassinoides-Phycodes represent combined dwelling-feeding structures.

In the trace fossil assemblage vertical or inclined burrows prevail, which suggests moderate to high energy conditions. However, the presence of horizontal structures (Phycodes, Gyrochorte and Planolites) and compound burrow systems (Thalassinoides-Phycodes) suggests episodes of low hydrodynamic conditions and availability of nutrients for tracemakers (deposit feeders) on the sea floor.

The trace fossils studied are characteristic of the Skolithos and Cruziana ichnofacies that typify the shallow marine (foreshore-middle shoreface). The sedimentation of the Coniacian sandstones may have taken place in an epicontinental sea, above fair-weather wave base, which is confirmed by the presence of sedimentary structures (planar lamination, trough cross-lamination and ripple marks), as well as a lack of hummocky cross-stratification (HCS).

The assemblage of trace fossils and associated body fossils, such as the gastropod Nerinea bicinct $a$ and the bivalve Lima haidingeri (which probably originate from Żeliszów Quarry) suggest that these sandstones were laid down in a soft-bottom environment, under normal oxygenation and salinity. This interpretation is in agreement with views expressed by Milewicz (1997), who reported a shallow epicontinental basin as the environment for Coniacian sandstones (Żerkowice Member, Rakowice Wielkie Formation).

The present ichnological analyses support the sedimentological reconstruction by Leszczyński (2010), who interpreted the Coniacian sandstones at Rakowice Małe Quarry as bar and storm deposits and suggested mainly the foreshore-upper shoreface as the former environment. The present study demonstrates that the presence of the more diverse trace fossil assemblage in sandstones from the Czaple-Nowa Wieś Grodziska quarries may suggest deposition of these deposits up to the middle shoreface, comparable to the sandstones at Żerkowice Quarry. Deposition of these sandstones was related to the regression that started after the transgressive peak (late Turonian/early Coniacian) in the North Sudetic Synclinorium. The southeastern part of the basin was uplifted (see Milewicz, 1997).

The presence of the gastropod Nerinea bicinc$t a$, with warm-water affinities, confirms the view that in the Upper Cretaceous basins of the Sudetes mixed assemblages typical of both Tethys Ocean and North Sea occurred, as previously suggested. However, the occurrence of Cyrena cretacea in Santonian deposits underscores mesohaline conditions in the Late Cretaceous sea that started to withdraw from the Sudetes.

\section{Acknowledgements}

We thank Alfred Uchman (Jagiellonian University, Kraków) for some remarks, Aleksander Kowalski (University of Wrocław) for supplying a few specimens for study, Kamil Pluta (University of Wrocław) for photographs of gastropods and bivalves and anonymous reviewers for helpful comments on an earlier version of the typescript.

\section{References}

Abbassi, N., 2007. Shallow marine trace fossils from Upper Devonian sediments of the Kuh-e Zard, Zefreh area, Central Iran. Iranian Journal of Science \& Technology, Transaction A 31, No A1, 23-33.

Abbassi, N., Shirazi, M.P \& Hosseinzadeh, M.A., 2015. Thalassinoides-Phycodes compound trace fossils from Albian-Cenomanian sediments of Gazk, South Kerman, SE Iran. Geosciences, Stratigraphy \& Sedimentology $24,145-152$.

Aceñolaza, F.G., Carlorosi, J. \& Heredia, S., 2010. Trazas Fósiles Y Conodontes En El Ordovícico Del Flanco Occidental De La Cuesta De Lipán, Departamento Purmamarca, Jujuy. Revista de la Asociacion Geológica Argentina 66, 164-170.

Alexandrowicz, S.W., 1976. Foraminifera from the brackish Santonian deposits in the North Sudetic Basin (Western Poland). Rocznik PTG, Annales de la Société Géologique de Pologne 46, 183-195.

Alexandrowicz, S. \& Kwiecińska, B., 1977. Amber from the Upper Cretaceous deposits of SW Poland. Mineralogia Polonica 8, 39-47. 
Anderson, B.G. \& Droser, M.L., 1998. Ichnofabrics and geometric configurations of Ophiomorpha within a sequence stratigraphic framework: an example from the Upper Cretaceous USA western interior. Sedimentology 45, 379-396.

Andert, H., 1934. Die Kreideablagerungen zwischen Elbe und Jeschken. Teil 3: Die Fauna der obersten Kreide in Sachsen, Bohmen und Schlesien. Abhandlungen der Preussischen Geologischen Landesanstalt, Neue Folge 159, Berlin, 1-477.

Baranowski, Z., Haydukiewicz, A., Kryza, R., Lorenc, S., Muszyński, A., Solecki, A. \& Urbanek, Z., 1990. Outline of the Góry Kaczwskie (Sudetes, Poland). Neues Jahrbuch für Geologie und Pälaontologie, Abhandlungen 179, 223-257.

Baucon, A. \& Neto de Carvalho, C., 2016. Stars of the aftermath; Asteriacites beds from the Lower Triassic of the Carnic Alps (Werfen Formation, Sauris di Sopra), Italy. Palaios 31, 161-176.

Baucon, A., Ronchi, A., Felletti, F. \& Neto de Carvalho, C., 2014. Evolution of Crustaceans at the edge of the end-Permian crisis: Ichnonetwork analysis of the fluvial succession of Nurra (Permian-Trassic, Sardinia, Italy). Palaeogeography, Palaeoclimatology, Palaeoecology 410, 74-103.

Bayet-Goll, A. \& Neto de Carvalho, C., 2016. Ichnology and sedimentology of a tide-influenced delta in the Ordovician from the northeastern Alborz range of Iran (Kopet Dagh region). Lethaia 49, 327-350.

Bayet-Goll, A., Neto de Carvalho, C., Mahmudy-Gharaei, M.H. \& Nadaf, R., 2015. Ichnology and sedimentology of a shallow marine Upper Cretaceous depositional system (Neyzar Formation, Kopet-Dagh, Iran): Palaeoceanographic influence on ichnodiversity. Cretaceous Research 56, 628-646.

Belaústegui, F. \& Muñiz, F., 2016. Ichnology of the Lepe area (Huelva, SW Spain): trace fossils at the Pliocene 'Arroyo Valleforero' section and modern traces at the Piedras Estuary. Comunicações Geológicas 103, 131-142.

Biernacka, J. \& Józefiak, M, 2009. The Eastern Sudetic Island in the Early-to-Middle Turonian: evidence from heavy minerals in the Jerzmanice sandstones, SW Poland. Acta Geologica Polonica 59, 545-565.

Billings, E., 1862. New species of Lower Silurian fossils. Geological Survey, Canada, 426 pp.

Bjerstedt, T.W., 1987. Latest Devonian - Earliest Mississippian nearshore trace-fossil assemblages from West Virginia, Pennsylvanian, and Maryland. Journal of Paleontology 61, 865-889.

Bjerstedt, T.W. \& Erickson, J.M., 1989. Trace fossils and bioturbation in peritidal facies of the Potsdam-Theresa formations (Cambrian-Ordovician), northwest Adirondacks. Palaios 4, 203-224.

Bressan, G.S., Kietzmann, D.A. \& Palma, R.M., 2013. Facies analysis of a Toarcian-Bajocian shallow marine/coastal succession (Bardas Blancas Formation) in northern Neuquén Basin, Mendoza province, Argentina. Journal of South American Earth Sciences 43, 112-126.

Bromley, R.G., 1996. Trace Fossils. Biology, Taphonomy and Applications. Chapman and Hall. London, 361 pp.
Bronn, H.G., 1836. Übersicht und abbildungen der bis jetzt bekannten Nerinea-Arten. Neues Jahrbuch für Mineralogie, Geologie und Petrefaktenkünde 4, 544-566.

Buatois, L.A., 2018. Treptichnus pedum and the Ediacaran-Cambrian boundary: siginificance and caveats. Geological Magazine 155, 174-180.

Buatois, L.A. \& Mángano, M.G., 1993. The ichnotaxonomic status of Plangtichnus and Treptichnus. Ichnos 2, 217-224.

Buatois, L.A. \& Mángano, M.G., 2011. Ichnology: Organism-Substrate Interactions in Space and Time. Cambridge University Press, 368 pp.

Buatois L.A. \& Mángano M.G., 2013. Ichnodiversity and ichnodisparity: significance and caveats. Lethaia 46, 281-292.

Buatois, L.A., Almond, J. \& Germs, G.J.B., 2013. Environmental tolerance and range offset of Treptichnus pedum: Implications for the recognition of the Ediacaran-Cambrian boundary. Geology 41, 519-522.

Buatois L.A., Carmona N.B., Curran H.A., Netto R.G., Mángano M.G. \& Wetzel A., 2016. The Mesozoic Marine Revolution. [In:] M.G. Mángano \& L.A. Buatois (Eds): The Trace-Fossil Record of Major Evolutionary Events. Volume 2: Mesozoic and Cenozoic 19-134.

Cataldo, C.S., 2013. A new Early Cretaceous nerineoid gastropod from Argentina and its palaeobiogeographic and palaeoecological implications. Cretaceous Research 40, 51-60.

Chen, Z-Q., Tong, J. \& Fraiser, M.L., 2011. Trace fossil evidence for restoration of marine ecosystems following the end-Permian mass extinction in the Lower Yangtze region, South China. Palaeogeography, Palaeoclimatology, Palaeoecology 299, 449-474.

Chlupáč, I., 1997. Palaeozoic ichnofossils in phyllites near Železný Brod, northern Bohemia. Journal of the Czech Geological Society 42, 75-94.

Chrząstek, A., 2002. Stratigraphy and sedimentation conditions of Röt and Lower Muschelkalk of the North Sudetic Basin. Acta Universitatis Wratislaviensis 2383, Prace Geologiczno-Mineralogiczne 73, 1-112 [In Polish with English summary].

Chrząstek, A., 2008. A new Coniacian fauna from the Jerzmanice Zdrój region of the North Sudetic Basin, SW Poland. Geologia Sudetica 40, 33-50.

Chrząstek, A., 2013a. Trace fossils from the Lower Muschelkalk of Raciborowice Górne (North Sudetic Synclinorium, SW Poland) and their palaeoenvironmental interpretation. Acta Geologica Polonica 63, 315-353.

Chrząstek, A., 2013b. Middle Turonian trace fossils from the Bystrzyca and Długopole sandstones in the Nysa Kłodzka Graben (Sudety, SW Poland). Geological Quarterly 57, 443-466.

Chrząstek, A. \& Wojewoda, J. 2011. Mesozoic of South-Western Poland (The North Sudetic Synclinorium). [In:] A. Żelaźniewicz, J. Wojewoda \& W. Ciężkowski (Eds): Mezozoik i Kenozoik Dolnego Ślas$k a$ [Mesozoic and Cenozoic of the Lower Silesia], WIND, Wrocław, 1-10 [In Polish with English summary].

Chrząstek, A., Kosarewicz, U. \& Raczyński, P., 2004. Cechsztyn i trias w niecce północnosudeckiej [Zechstein and Triassic in the North Sudetic Basin]. [In:] 
J. Muszer (Ed.): Zapis paleontologiczny jako wskaźnik paleośrodowisk [Palaeontological record as palaeoenvironmental indicator]. Wrocław, 108-112 [In Polish].

Chrząstek, A., Muszer, J., Solecki, A. \& Sroka, A.M., 2018. Rosarichnoides sudeticus igen. et isp. nov. and associated fossils from the Coniacian of the North Sudetic Synclinorium (SW Poland). Geological Quarterly 62, 181-196.

Curran, H.A., 1984. Ichnology of Pleistocene carbonates on San Salvador, Bahamas. Journal of Paleontology 58, 312-321.

Curran, H.A., 1985. The trace fossil assemblage of a Cretaceous nearshore environment: Englishtown Formation of Delaware, U.S.A. SEPM Special Publication 35, 261-276.

Curran, H.A., 2007. Ichnofacies, ichnocoenoses, and ichnofabrics of Quaternary shallow-marine to dunal tropical carbonates: A model and implications. [In:] W. Miller III (Ed.): Trace Fossils. Concepts, Problems, Prospects 232-247.

Curran, H.A. \& White, B., 1991. Trace fossils of shallow subtidal to dunal ichnofacies in Bahamian Quaternary carbonates. Palaios 6, 498-510.

Desai, B.G., Shukla, R. \& Saklani, R.D., 2010. Ichnology oft he Early Cambrian Tal Group, Nigalidhar Syncline, Lesser Himalaya, India. Ichnos 17, 233-245.

De Grave, S., Pentcheff, N.D., Ahyong, S.T., Chan, T.-Y., Crandall, K.A., Dworschak, P.C., Felder, D.L., Feldmann, R.M., Fransen, C.H.J.M., Goulding, L.Y.D., Lemaitre, R., Low, M.E.L., Martin, J.W., Ng, P.K.L., Schweitzer, C.E., Tan, S.H., Tshudy, D. \& Wetzer, R., 2009. A classification of living and fossil genera of decapod crustaceans. Raffles Bulletin of Zoology, Supplement 21, 1-109.

Dott, R.H. \& Bourgeois, J., 1982. Hummocky stratification: Significance of its variable bedding sequences. Geological Society of American Bulletin 93, 663-680.

Drescher, R., 1863. Ueber die Kreide-Bildungen der Gegend von Löwenberg. Zeitschrift der Deutschen Geologischen Gesselschaft 14, 291-366.

Duke, W.L., 1985. Hummocky cross-stratification, tropical hurricanes, and intense winter storms. Sedimentology 32, 167-194.

Dworschak, P.C., 2000. The burrows of Callianassa tyrrhena (Petagna 1792) (Decapoda: Thalassinidea). Marine Ecology 22, 155-166.

Ehrenberg, K., 1944. Ergänzende Bemerkungen zu den seinerzeit aus dem Miozän von Burgschleinitz beschrieben Gangkernen und Bauten dekapoder Krebse. (Supplementary remarks on burrow-fills and structures of decapod crustaceans, previously described from the Miocene of Burgschleinitz.) Paläontologische Zeitschrift 23, 345-359.

Ekdale, A.A. \& Bromley, R.G., 2003. Paleoethologic interpretation of complex Thalassinoides in shallow-marine limestones, Lower Ordovician, southern Sweden. Palaeogeography, Palaeoclimatology, Palaeoecology 192, 221-227.

El-Hedeny, M., Hewaidy, A. \& Al-Kahtany, Kh., 2012. Shallow-marine trace fossils from the Callovian-Oxfordian Tuwaiq Mountain limestone and Hanifa For- mations, central Saudi Arabia. Australian Journal of Basic and Applied Sciences 6, 722-733.

Fillion, D. \& Pickerill, R.K., 1990. Ichnology of the Upper Cambrian? To Lower Ordovician Bell Island and Wabana groups of eastern Newfoundland, Canada. Palaeontographica Canadiana 7, 1-119.

Földvary, G.Z., 1988. Geology of the Carpathian Region. World Scientific Publishing Co, Singapore, 573 pp.

Frey, R.W., 1990. Trace fossils and hummocky cross-stratification, Upper Cretaceous of Utah, Palaios 5, 203-218.

Frey, R.W. \& Howard, J.D., 1990. Trace fossils and depositional sequences in a clastic shelf setting. Upper Cretaceous of Utah. Journal of Paleontology 64, 803-820.

Frey, R. W. \& Seilacher, A., 1980. Uniformity in marine invertebrate ichnology. Lethaia 13, 183-207.

Frey, R.W., Curran, H.A. \& Pemberton, S.G., 1984. Tracemaking activities of crabs and their environmental significance: the ichnogenus Psilonichnus. Journal of Paleontology 58, 333-350.

Frey, R.W., Howard, J.D. \& Pryor, W.A., 1978. Ophiomorpha: Its morphologic, taxonomic, and environmental significance. Palaeogeography, Palaeoclimatology, Palaeoecology 23, 199-229.

Frey, S.E. \& Dashtgard, S.E., 2011. Sedimentology, ichnology and hydrodynamics of strait-margin, sand and gravel beaches and shorefaces: Juan de Fuca Strait, British Columbia, Canada. Sedimentology 58, 13261346.

Fürsich, F.T., Wilmsen, M. \& Seyed-Emami, K., 2006. Ichnology of Lower Jurassic beach deposits in the Shemshak Formation at Shahmirzad, southeastern Alborz Mountains, Iran. Facies 52, 599-610.

Gibert, J.M. \& Benner, J.S., 2002. The trace fossil Gyrochorte: ethology and paleoecology. Revista Española de Paleontologia 17, 1-12.

Gibert, J.M. de \& Ekdale, A.A. 2002. Ichnology of a restricted epicontinental sea, Arapien Shale, Middle Jurassic, Utah, USA. Palaeogeography, Palaeoclimatology, Palaeoecology 183, 275-286.

Gibert, J.M. de, Netto, R.G., Tognoli, F.M. \& Grangeiro, M.F., 2006. Commensal worm traces and possible juvenile thalassinidean burrows associated with Ophiomorpha nodosa, Pleistocene, Southern Brazil. Palaeogeography, Palaeoclimatology, Palaeoecology 230, 70-84.

Goldring, R. \& Pollard, J.E., 1995. A re-evaluation of Ophiomorpha burrows in the Wealden Group (Lower Cretaceous) of southern England. Cretaceous Research 16, 665-680.

Gorczyca-Skała, J., 1977. Budowa geologiczna rowu Wlenia [Geologic structure of the Wlen Graben]. Geologia Sudetica 12, 71-100.

Gradziński, R. \& Uchman, A., 1994. Trace fossils from interdune deposits - an example from the Lower Triassic Aeolian Tumlin Sandstone, central Poland. Palaeogeography, Palaeoclimatology, Palaeoecology 108, 121-138.

Greguš, J., Kvaček, J. \& Halamski, A.T., 2013. Revision of Protopteris and Oncopteris tree fern stem casts from the Late Cretaceous of Central Europe. Acta Musei Nationalis Pragae Series B - Historia Naturalis 69, 69-83. 
Griffis, R.B. \& Suchanek, T.H., 1991. A model of burrow architecture and trophic modes in thalassinidean shrimp (Decapoda: Thalassinidea). Marine Ecology Progress Series 79, 171-183.

Halamski, A.T. \& Kvaček, J., 2015. Late Cretaceous (Coniacian) leaf and cone flora from the Sudetes. Palaeontographica, Abt. B: Palaeobotany-Palaeophytology 292, 95-171.

Halamski, A.T. \& Kvaček, J., 2016. The Coniacian leaf flora from the northeastern part of the Bohemian Cretaceous Basin. Bulletin of Geosciences 91, 297-318.

Hall, J., 1852. Paleontology of New York 2C. Van Benthuysen, Albany, 362 pp.

Hampson, G.I. \& Storms, I.E.A., 2003. Geomorphological and sequence stratigraphic variability in wave-dominated, shoreface-shelf parasequences. Sedimentology 50, 667-701.

Han, Y. \& Pickerill, R.K., 1994. Phycodes templus isp. nov. from the Lower Devonian of northwestern New Brunswick, eastern Canada. Atlantic Geology 30, 37-46.

Hanken, N.-M., Uchman, A., Nielsen, J.K., Olaussen, S., Eggebø, T. \& Steinsland, R., 2016. Late Ordovician trace fossils from offshore to shallow water mixed siliciclastic and carbonate facies in the Ringerike Area, Oslo Region, Norway. Ichnos 23, 189-221.

Häntzschel, W., 1975. Trace fossils and problematica. [In:] T. Teichert (Ed.), Treatise on Invertebrate Paleontology, Part W, Miscellanea Supplement I. Geological Society of America and University of Kansas, 269 pp.

Heer, O., 1865. Die Urwelt der Schweiz. Friedrich Schultez, Zürich, 622 pp.

Heinberg, C. \& Birkelund, T., 1984. Trace-fossil assemblages and basin evolution of the Vardekloft Formation (Middle Jurassic, Central East Greenland). Journal of Paleontology 58, 362-397.

Hembree, D.I., Nadon, G.C. \& King, M.R., 2011. Large, complex burrow systems from freshwater deposits of the Monongahela Group (Virgilian), Southeast Ohio, USA. Palaeogeography, Palaeoclimatology, Palaeoecology 300, 128-137.

Hofmann, R., Mángano, M.G., Elicki, O. \& Shinaq, R., 2012. Paleoecologic and biostratigraphic significance of trace fossils from shallow- to marginal-marine environments from the Middle Cambrian (Stage 5) of Jordan. Journal of Paleontology 86, 931-955.

Howard, J.D. \& Frey, R.W., 1984. Characteristic trace fossils in nearshore to offshore sequences, Upper Cretaceous of east-central Utah. Canadian Journal of Earth Sciences 21, 200-219.

Howell, J.A., Flint, S.S. \& Hunt, C., 1996. Sedimentological aspects of the Humber Group (Upper Jurassic) of the South Central Graben, UK North Sea. Sedimentology 43, 89-114.

Hubbard, S.M., MacEachern, J.A. \& Bann, K.L., 2012. Slopes. [In:] D. Knaust \& R.G. Bromley (Eds): Trace fossils as indicators of sedimentary environments, Developments in Sedimentology 64, 607-642.

Jackson, A.M., Hasiotis, S.T. \& Flaig, P.P., 2016. Ichnology of a paleopolar, river-dominated, shallow marine deltaic succession, Central Transantarctic Mountains,
Anttarctica. Palaeogeography, Palaeoclimatology, Palaeoecology 441, 266-291.

Jensen, S., 1997. Trace fossils from the Lower Cambrian Mickwitzia sandstone, south-central Sweden. Fossils and Strata 42, Oslo, 1-110.

Jensen, S. \& Grant, S.W.F., 1998. Trace fossils from the Dividalin Group, northern Sweden: implications for Early Cambrian biostratigraphy of Baltica. Norsk Geologisk Tidsskrift 78, 305-317.

Jin, J., Harper, D.A.T., Rasmussen, J.A. \& Sheehan, P.M., 2011. Late Ordovician massive-bedded Thalassinoides ichnofacies along the palaeoequator of Laurentia. $\mathrm{Pa}$ laeogegraphy, Palaeoclimatology, Palaeoecology 367-368, 73-88.

Joseph, J.K. \& Patel, S.J., 2015. Ichnology of mixed siliciclastic-carbonate sedimentary cycles and their sequence stratigraphic context: Kaladongar Formation (Middle Jurassic) of Kachchh, western India. Volumina Jurassica XIII, 81-100.

Joseph, J.K., Patel, S.J. \& Bhatt, N.Y., 2012. Trace fossil assemblages in mixed siliciclastic-carbonate sediments of the Kaladongar Formation (Middle Jurassic), Patchans Island, Kachchh, Western India. Journal Geological Society of India 80, 189-214.

Keferstein, C., 1828. Deutschland, geologisch-geognostisch dargestellt und mit Karten und Durchschnittszeichnungen erläutert, Band 5, Heft 3. Weimar.

Keighley, D.G. \& Pickerill, R.K., 1995. Commentary: the ichnotaxa Palaeophycus and Planolites, historical perspective and recommendations. Ichnos 3, 301-309.

Kim, J.Y. \& Kim, K.-S., 2002. Cretaceous nonmarine trace fossils from the Hasandong and Jinju formations on the Namhae Area, Kyongsangnamdo, Southeast Korea. Ichnos 9, 41-60.

Kim, J.-Y., Kim, K.-S. \& Pickerill, R.K., 2002. Cretaceous nonmarine trace fossils from the Hasandong and Jinju Formations of the Namhae Area, Kyongsangnamdo, southeast Korea. Ichnos 9, 41-60.

Klinghardt, F. von, 1944. Das Kronner-Riff (Gosauschichten) im Lattengebirge. Mittelungen des Alpenländischen geologischen Vereines (Mittelungen der geologischen Gesellschaft in Wien) 35, 1942, 179-213.

Knaust, D., 2004. Cambro-Ordovician trace fossils from the SW-Norwegian Caledonides. Geological Journal 39, 1-24.

Knaust, D., 2007. Invertebrate trace fossils and ichnodiversity in shallow-marine carbonates of the German Middle Triassic (Muschelkalk). Sediment-Organism Interactions: A Multifaceted Ichnology, SEPM Special Publication 88, 221-238

Kollmann, H.A., 2014. The extinct Nerineoidea and Acteonelloidea (Heterobranchia, Gastropoda): a palaeobiological approach. Geodiversitas, Paris 36, 349-383.

Košt'ák, M., Čech, S., Uličný, D., Sklenář, J., Ekrt, B. \& Mazuch, M., (in press). Ammonites, inoceramids and stable carbon isotopes of the Cenomanian - Turonian OAE2 interval in central Europe : Pecínov quarry, Bohemian Cretaceous Basin (Czech Republic). Cretaceous Research, http://dx.doi.org/10.1016/j.cretres.2017.04.013. 
Kryza, R., Zalasiewicz, J., Mazur, S., Aleksandrowski, P., Sergeev, S. \& Larionov, A. 2007. Precambrian crustal contribution to the Variscan accretionary prism of the Kaczawa Mountains, Sudetes, SW Poland: evidence from SHRIMP dating of detrital zircons. Geologische Rundschau 96, 1153-1162.

Książkiewicz, M., 1977. Trace fossils in the Flysch of the Polish Carpathians. Palaeontologia Polonica 36, 1-208.

Kvaček, J., Halamski, A.T., Svobodova, M. \& Durska, E., 2015. Coniacian flora of the Sudetes (south-western Poland): Palaeoecological and palaeoclimatic interpretations. Palaeogeography, Palaeoclimatology, Palaeoecology 436, 178-187.

Leaman, M., Mcllroy, D., Herringshaw, L.G., Boyd, C. \& Callow, R.H.T., 2015. What does Ophiomorpha irregulaire really look like? Palaeogeography, Palaeoclimatology, Palaeoecology 439, 38-49.

Leszczyński, S., 2010. Coniacian-?Santonian paralic sedimentation in the Rakowice Małe area of the North Sudetic Basin, SW Poland: Sedimentary facies, ichnological record and palaeogeographical reconstruction of an evolving marine embayment. Annales Societatis Geologorum Poloniae 80, 1-24.

Lommel, J., 1841. Allgemeines Repertorium der Mineralogie, Geognosie, Geologie und Petrefakten-Kunde für das Dezzenium 1830-1839, ein Personal-, Realund Lokal-Index zu "v. Leonards und Bronns. Jahrbuch für Mineralogie, Geognosie und Petrefakten-Kunde", Jahrgänge 1830-1839. E. Schwizerbart'sche Verlagshandlung, Stuttgart.

Lundgren, B., 1891. Studier öfver fossiliförande lösa block. Geologiska Föreningens Stockholm Förhandlingar 13, 111-121.

MacEachern, J.A., Bann, K.L., Gingras, M.K., Zonneveld, J.-P., Dashtgard, S.E. \& Pemberton, S.G., 2012. The ichnofacies paradigm. [In:] D. Knaust \& R.G. Bromley (Eds): Trace fossils as indicators of sedimentary environments. Developments in Sedimentology 64, 103-138.

MacEachern, J.A., Pemberton, S.G., Gingras, M.K. \& Bann, K.L., 2007. The ichnofacies paradigm: a fifty-year retrospective. [In:] W. Miller (Ed.): Trace Fossils. Concepts, Problems, Prospects, Elsevier, 135-148.

Malpas, J.A., Gawthorpe, R.L., Pollard, J.E. \& Sharp, I.R., 2005. Ichnofabric analysis of the shallow marine Nukhul Formation (Miocene), Suez Rift, Egypt: implications for depositional processes and sequence stratigraphic evolution. Palaeogeography, Palaeoclimatology, Palaeoecology 215, 239-264.

Mángano, M.G. \& Buatois, L.A., 2016. The Cambrian Explosion. [In:] M.G. Mángano \& L.A. Buatois (Eds): The trace-fossil record of major evolutionary events. Volume 1: Precambrian and Paleozoic, Topics in Geobiology 39, 73-126.

Mángano, M.G., Buatois, L.A., Wilson, M.A. \& Droser, M., 2016. The Great Ordovician Biodiverification Event. [In:] M.G. Mángano \& L.A. Buatois (Eds): The Trace-Fossil Record of Major Evolutionary Events. Volume 1: Precambrian and Paleozoic, Topics in Geobiology 39, 127-156.

Mayoral, E., Ledesma-Vazgues, J., Baarli, B.G., Santos, A., Ramalho, R., Cachao, M., Silva, C.M. da \& Johnson,
M.E., 2013. Ichnology in oceanic islands; cuse studies from the Cape Verde Archipelago. Palaeogeography, Palaeoclimatology, Palaeoecology 381-382, 47-66.

McCann, T. \& Pickerill, R.K., 1988. Flysch trace fossils from the Cretaceous Kodiak Formation of Alaska. Journal of Paleontology 62, 330-348.

Merill, R.D., 1984. Ophiomorpha and other nonmarine trace fossils from the Eocene Ione Formation, California. Journal of Paleontology 58, 542-549.

Mieras, B.L., Sageman, B.B. \& Kauffman, E.G., 1993. Trace fossil distribution patterns in Cretaceous facies of the Western Interior Basin, North America. [In:] W.G.E. Caldwell \& E.G. Kauffman (Eds): Evolution of the Western Interior Basin: Geological Association of Canada, Special Papers 39, 585-620.

Mikuláš, R., 2000. Trace fossils from the Cambrian of the Barandian area. Czech Geological Survey Special Papers $12,1-29$.

Milewicz, J., 1973. Geological section through the North-Sudetic Depression. Kwartalnik Geologiczny 17, 45-56 [in Polish, summary in English and Russian].

Milewicz, J., 1979. Distribution of Cretaceous rocks in the North-Sudetic Basin. Kwartalnik Geologiczny 23, 819826 [in Polish with English summary].

Milewicz, J., 1985. Proposal of formal lithostratigraphic nomenclature from strata of the North-Sudetic Depression. Przeglad Geologiczny 33, 385-389 [in Polish, summary in English and Russian].

Milewicz, J., 1988. Cretaceous macrofauna in Węgliniec IG 1 borehole. Kwartalnik Geologiczny 32, 389-404.

Milewicz J., 1991. On development of the North Sudetic Cretaceous Basin. Biuletyn Państwowego Instytutu Geologicznego 367, 135-141 [in Polish with English summary].

Milewicz, J., 1997. Upper Cretaceous of the North-Sudetic depression (litho- and biostratigraphy, paleogeography, tectonics and remarks on raw materials. Prace Geologiczno-Mineralogiczne 61, Acta Universitatis Wratislaviensis 1971, 1-58 [in Polish with English summary].

Milewicz, J., 1998. Distribution of Coniacian sandstones in the North Sudetic Basin. Acta Universitatis Wratislaviensis 2004, Prace Mineralogiczno-Geologiczne 64, 101-109 [in Polish with English summary].

Miller, M.F. \& Curran, H.A., 2001. Behavioral plasticity of modern and Cenozoic burrowing thalassinidean shrimp. Palaeogeography, Palaeoclimatology, Palaeoecology 166, 219-236.

Miller, S.A., 1889. North American Geology and Paleontology for the Use of Amateurs, Students and Scientists. Western Methodist Book Concern, Cincinnati, 664 pp.

Miller, S.A. \& Dyer, C.B., 1878. Contribution to paleontology, no 1. Journal of the Cincinnati Society of Natural History 1, 24-39.

Miller, W., 1998. Complex marine trace fossils. Lethaia 31, 29-32.

Miller, W., 2001. Thalassinoides-Phycodes compound burrow systems in Paleocene deep-water limestone, Southern Alps of Italy. Palaeogeography, Palaeoclimatology, Palaeoecology 170, 149-156. 
Minter, N.J., Buatois, L.A. \& Mángano, M.G., 2016. The conceptual and methodological tools of ichnology. [In:] M.G. Mángano \& L.A. Buatois (Eds): The Trace-Fossil Record of Major Evolutionary Events, Vol. 2, The Mesozoic Marine Revolution, Topics in Geobiology 40, $1-26$.

Müller, G., 1888. Beiträge zur Kenntnis der oberen Kreideformation am nordlichen Harzrand. Jahrbuch der Preussischen Geologischen Landesanstalt und Bergacademie. Berlin, 8, 372-456.

Myrow, P.M., 1995. Thalassinoides and the enigma of Early Paleozoic open-framework burrow systems. Palaios $10,58-74$.

Nagy, J., Rodríguez-Tovar, F.J. \& Reolid, M., 2016. Environmental significance of Ophiomorpha in a transgressive-regressive sequence of the Spitsbergen Paleocene. Polar Research 35, 24192.

Neto de Carvalho, C.N., 2016. The massive death of lobsters smothered within their Thalassinoides burrows: the example of the lower Barremian from Lusitanian Basin (Portugal). Comunicações Geológicas 103, 143-152.

Neto de Carvalho, C.N., Pereira, B., Klompmaker, A., Baucon, A., Moita, J.A., Pereira, P., Machado, S., Belo, J., Carvalho, J. \& Mergulhão, L. 2016. Running crabs, walking crinoids, grazing gastropods: behavioral diversity and evolutionary implications of the Cabeço da Ladeira Lagerstätte (Middle Jurassic, Portugal). Comunicações Geológicas 103, 39-54.

Neto de Carvalho, C.N., Viegas, P.A. \& Cachão, M., 2007. Thalassinoides and its producer: populations of $\mathrm{Me}$ cochirus buried within their burrow systems, Boca do Chapim Formation (Lower Cretaceous), Portugal. Palaios 22, 104-109.

Nicholson, H.A., 1873. Contributions to the study of the errant annelids of the older Palaeozoic rock. Proceedings of the Royal Society of London 21, 288-290.

Olde, K., Jarvis, I., Pearce, M., Walaszczyk, I. \& Tocher, B., 2016. Organic-walled dinoflagellate cyst records from a prospective Turonian-Coniacian (Upper Cretaceous), Słupia Nadbrzeżna, Poland. Cretaceous Research 65, 17-24.

Osgood, R.G., 1970. Trace fossils of the Cincinnati area. Palaeontographica Americana 6, 277-444.

Paranjape, A.R., Kulkarni, K.G. \& Kale, A.S., 2014. Sea level changes in the upper Aptian-lower/middle(?) Turonian sequence of Cauvery Basin, India - An ichnological perspective. Cretaceous Research 56, 702-715.

Patel, S.J., Desai, B.G. \& Shukla, R., 2009. Paleoecological signifacance of the trace fossils of Dhosa Oolite Member (Jumara Formation), Jhura Dome, Mainland Kachchh, western India. Journal Geological Society of India 74, 601-614.

Pazos, P.J., Lazo, D.G., Tunik, M.A., Marsicano, C.A., Fernández, D.E. \& Aguirre-Urreta, M.B., 2012. Palaeoenvironmental framework of dinosaur tracksites and other ichnofossils in Early Cretaceous mixed siliciclastic-carbonate deposits in the Neuquén Basin, northern Patagonia (Argentina). Gondwana Research 22, 1125-1140.

Pearson, N.J., Mángano, M.G., Buatois, 1., Casadio, S. \& Raising, M.R., 2013. Environmental variability of Ma- caronichnus ichnofabrics in Eocene tidal-embayment deposits of southern Patagonia, Argentina. Lethaia 46, 341-354.

Pemberton, S.G. \& Frey, R.W., 1982. Trace fossil nomenclature and the Planolites-Palaeophycus dilemma. Journal of Paleontology 56, 843-881.

Pemberton, S.G., MacEachern, J.A., Dashtgard, S.E., Bann, K.L., Gingras, M.K. \& Zonneveld, J.-P., 2012. Shorefaces. [In:] D. Knaust D. \& R.G. Bromley (Eds): Trace fossils as indicators of sedimentary environments, Developments in Sedimentology 64, 563-603.

Pemberton, S.G., Spila, M., Pulham, A.J., Saunders, T., MacEachern, J.A., Robbins, D. \& Sinclair, I.K., 2001. Ichnology and sedimentology of shallow to marginal marine systems. Ben Nevis \& Avalon Reservoirs, Jeanne d'Arc Basin. Geological Association of Canada, Short Course Notes 15, 1-343.

Pervesler, P., Uchman, A., Hohenegger, J. \& Dominici, S., 2011. Ichnological record of environmental changes in Early Quaternary (Gelasian-Calabrian) marine deposits of the Stirone section, Northern Italy. Palaios 26, 578-593.

Pickerill, R.K., 1994. Nomenclature and taxonomy of invertebrate trace fossils. [In:] S.K. Donovan (Ed.): The Palaeobiology of Trace Fossils. John Wiley, Chichester, 3-42.

Pickerill, R.K., Norman, Y. \& Han, Y., 1995. New occurrence of Phycodes templus Han and Pickerill, 1884 with a taxonomic reassessment of Yangziichnus yichangensis Yang, 1984. Atlantic Geology 31, 1-5.

Pollard, J.E., 1981. A comparison between the Triassic trace fossils of Cheshire and south Germany. Palaeontology 24, 555-588.

Pollard, J.E., Goldring, R. \& Buck, S.G., 1993. Ichnofabrics containing Ophiomorpha: significance in shallow-water interpretation. Journal of the Geological Society 150, 149-439.

Richter, R., 1850. Aus der thuringischen Grauwacke. Deutsche Geologische Gesellshaft, Zeitschrift 2, 198-206.

Richter, R., 1853. Thüringischen Graptolithen. Zeitschrift der Deutschen Geologische Gesselschaft 5, 439-451.

Richter, R., 1937. Marken und Spuren aus alten Zeiten III. Senckenbergiana 19, 150-178.

Rieth, A., 1932. Neue Funde spongeliomorpher Fucoiden aus Jura Schwabens. Geologische Pälaontologische Abhandlungen, Neue Folge 19, 257-294.

Rindsberg, A.K. \& Martin, A.J., 2003. Arthrophycus in the Silurian of Alabama (USA) and the problem of compound trace fossils. Palaeogeography, Palaeoclimatology, Palaeoecology 192, 187-219.

Rodríguez-Tovar, F.J., Miguez-Salas, O. \& Duarte, L.V., 2017. Toarcian Oceanic Anoxic Event induced unusual behavior and palaeobiological changes in Thalassinoides tracemakers. Palaeogeography, Palaeoclimatology, Palaeoecology 485, 46-56.

Rodríguez-Tovar, F.J., Puga-Bernabéu, Á. \& Buatois, L.A., 2008. Large burrow systems in marine Miocene deposits of the Betic Cordillera (Southeast Spain). Palaeogeography, Palaeoclimatology, Palaeoecology 268, 19-25.

Rodríguez-Tovar, F.J., Stachacz, M., Uchman, A. \& Reolid, M., 2014. Lower/Middle Ordovician (Arenigian) 
shallow-marine trace fossils of the Pochico Formation, southern Spain: palaeoenvironmental and palaeogeographic implications at the Gondwanan and peri-Gondwanan realm. Journal of Iberian Geology 40, 539-555.

Sanders, D., 1998. Tectonically controlled Late Cretaceous terrestrial to neritic deposition (Northern Calcareous Alps, Tyrol, Austria). Facies 39, 139-178.

Saul, L.R. \& Squires, R.L., 1998. New Cretaceous gastropods from California. Palaeontology 41, 461-488.

Savrda, C.E., Counts, J.W., Bigham, E. \& Martin, S., 2010. Ichnology of siliceous facies in the Eocene Tallahatta Formation (eastern United States Gulf Coastal Plain): implications for depositional conditions, storm processes, and diagenesis. Palaios 25, 642-655.

Schlirf, M., 2000. Upper Jurassic trace fossils from the Boulonnais (northern France). Geologica et Palaeontologica 34, 145-213.

Schlirf, M., 2003. Palaeoecologic significance of Late Jurassic trace fossils from the Boulonnais, N France. Acta Geologica Polonica 53, 123-142.

Scupin, H., 1912-1913. Die Löwenberger Kreide und ihre Fauna. Paleontographica, Stuttgart, 275 pp.

Seidler, L. \& Steel, R., 2001. Pinch-out style and position of tidally influenced strata in a regressive-transgressive wave-dominated deltaic sandbody, Twentymile sandstone, Mesaverde Group, NW Colorado. Sedimentology 48, 399-414.

Seilacher, A., 2000. Ordovician and Silurian arthrophycid ichnostratigraphy. [In:] Sola, M.A. \& Worsley, D. (Eds): Geological Exploration in Murzuq Basin. Elsevier, Amsterdam, pp. 237-258.

Shahkarami, S., Mangano, M.G. \& Buatois, L.A., 2017. Discriminating ecological and evolutionary controls during the Ediacaran-Cambrian transition: Trace fossils from the Soltanieh Formation of northern Iran. Palaeogeography, Palaeoclimatology, Palaeoecology 476, 15-27.

Sheehan, P.M. \& Schiefelbein, D.R.J., 1984. The trace-fossil Thalassinoides from the Upper Ordovician of the Eastern Great basin: deep burrowing in the Early Paleozoic. Journal of Paleontology 58, 440-447.

Shi, G., Woods, A.D., Yu, M. \& Wei, H., 2015. Two episodes of evolution of trace fossils during the Early Triassic in the Guiyang area, Guizhou Province, South China. Palaeogeography, Palaeoclimatology, Palaeocology 426, 275-284.

Singh, B.P., Bhargava, O.N., Mikuláš, R., Prasad, S.K., Singla, G. \& Kaur R., 2017. Asteriacites and other trace fossils from the Po Formation (Visean-Serpukhovian), Ganmachidam Hill, Spiti Valley (Himalaya) and its paleoenvironmental significance. Geologia Carpathica 68, 464-478.

Singh, R.H., Rodríguez-Tovar, F.J. \& Ibotombi, S., 2008. Trace fossils of the Upper Eocene - Lower Oligocene transition of the Manipur, Indo-Myanmar Ranges (Northeast India). Turkisch Journal of Earth Sciences 17, 821-834.

Sohl, N.F., 1987. Cretaceous gastropods: contrasts between Tethys and temperate provinces. Journal of Paleontology 61, 1085-1111.
Sohl, N.F \& Kollmann, H.A., 1985. Cretaceous Actaeonellid Gastropods from the Western Hemisphere. US Geological Survey Professional Paper 1304, 1-97.

Sprechmann, P., Gaucher, C., Blanco, G. \& Montaña, J., 2004. Stromatolitic and trace fossils community of the Cerro Victoria Formation, Arroyo del Soldado Group (Lowermost Cambrian, Uruguay). Gondwana Research 7, 753-766.

Srivastava, P., 2012. Treptichnus pedum: An ichnofossil representing Ediacaran-Cambrian boundary in the Nagaur Group, the Marwar Supergroup, Rajasthan, India. Proceedings of the National Academy of Sciences, India 78, 161-169.

Stachacz, M., 2012. Ichnology of Czarna Shale Formation (Cambrian, Holy Cross Mountains, Poland). Annales Societatis Geologorum Poloniae 82, 105-120.

Stachacz, M., 2016. Ichnology of the Cambrian Ociesęki Sandstone Formation (Holy Cross Mountains, Poland). Annales Societatis Geologorum Poloniae 86, 291328.

Stamhuis, E.J. \& Videler, J.J., 1998. Burrow ventilation in the tube-dwelling shrimp Callianassa subterranea (Decapoda: Thalassinidea). The Journal of Experimental Biology 201, 2151-2158.

Stille, H., 1924. Grundfragen der vergleichenden Tektonik. Borntraeger Verh., Berlin.

Suchanek, T.H., Colin, P.L., McMurtry, G.M. \& Suchanek, C.S., 1986. Bioturbation and redistribution of sediment radionuclides in Enewetak Atoll lagoon by callianassid shrimp: Biological aspects. Bulletin of Marine Science 38, 144-154.

Swinbanks, D.D. \& Luternauer, J.L., 1987. Burrow distribution of thalassinidean shrimp on a Fraser Delta tidal flat, British Columbia. Journal of Paleontology 61, 315-322.

Śliwiński, W., Raczyński, P. \& Wojewoda, J., 2003. Sedymentacja utworów epiwaryscyjskiej pokrywy osadowej w basenie północnosudeckim [Deposition of the epiwariscan cover in the North Sudetic Basin]. [In:] W. Ciężkowski, J. Wojewoda, J. \& A. Żelaźniewicz (Eds): Sudety Zachodnie: od wendu do czwartorzędu [The Western Sudetes: since Vendian till Quaternary]. Polskie Towarzystwo Geologiczne, Wrocław, 119-126 [in Polish].

Tchoumatchenco, P. \& Uchman, A., 2001. The oldest deep-sea Ophiomorpha and Scolicia and associated trace fossils from the Upper Jurassic-Lower Cretaceous deep-water turbidite deposits of SW Poland. Palaeogeography, Palaeoclimatology, Palaeoecology 169, 85-99.

Tiedt, L., 1958. Die Nerineen der österreichischen Gosauschichten, Paläontologisches Institut der Universität Wien, Akademie der Wissenschaften, Wien, 483-517.

Tiwari, R.P., Rajkonwar, C., Lalchawimawii, Malsawma, P.L.J., Ralte, V.Z. \& Patel, S.J., 2011. Trace fossils from Bhuban Formation, Surma Group (Lower to Middle Miocene) of Mizoram India and their palaeoenvironmental significance. Journal of Earth System Science 6, 1127-1143.

Uchman, A., 1991. "Shallow water" trace fossils in Paleogene flysch of the southern part of the Magura 
Nappe, Polish Outer Carpathians. Annales Societatis Geologorum Poloniae 61, 61-75.

Uchman, A., 1992. Ichnogenus Rhizocorallium in the Paleogene flysch (outer Western Carpathians, Poland). Geologica Carpathica 43, 57-60.

Uchman, A., 1998. Taxonomy and ethology of flysch trace fossils: revision of the Marian Książkiewicz collection and studies of complementary material. Annales Societatis Geologorum Poloniae 68, 1-105.

Uchman, A., 2009. The Ophiomorpha rudis ichnosubfacies of the Nereites ichnofacies: Characteristics and constraints. Palaeogeography, Palaeoclimatology, Palaeoecology 276, 107-119.

Uchman, A. \& Demircan, H., 1999. Trace fossils of Miocene deep-sea fan fringe deposits from the Cingoz Formation, southern Turkey. Annales Societatis Geologorum Poloniae 69, 125-135.

Uchman, A. \& Gaździcki, A., 2006. New trace fossils from the La Meseta Formation (Eocene) of Seymour Island, Antarctica. Polish Polar Research 27, 153-170.

Uchman, A. \& Krenmayr, H. G., 2004. Trace fossils, ichnofabrics and sedimentary facies in the shallow marine Lo Miocene Molasse of Upper Austria. Jahrbuch der Geologischen Bundesanstalt 144, 233-251.

Uchman, A. \& Tchoumatchenco, P., 2003. A mixed assemblage of deep-sea and shelf trace fossils from the Lower Cretaceous (Valanginian) Kamchia Formation in the Troyan Region, Central Fore-Balkan, Bulgaria. Annales Societatis Geologorum Poloniae 73, 27-34.

Voigt, S., Wagreich, M., Surlyk, F., Walaszczyk, I., Uličny, D., Čech, S., Voigt, T., Wiese, F., Wilmsen, M., Niebuhr, B., Reich, M., Funk, H., Michalík, J., H., Jagt, J.W.M., Felder, P.J. \& Schulp, A.S., 2008. Cretaceous. In: T.P. McCann [Ed.]: The Geology of Central Europe, Vol. 2. Mesozoic and Cenozoic. Geological Society of London, 923-998.

Voigt, T., Eynatten, H. von \& Franzke, H.-J., 2004. Late Cretaceous unconformities in the Subhercynian Cretaceous Basin (Germany). Acta Geologica Polonica 54, 673-694.

Walaszczyk, I., 1992. Turonian through Santonian deposits of the Central Polish Uplands; their facies development, inoceramid paleontology and stratigraphy. Acta Geologica Polonica 42, 1-122.

Walaszczyk, I. \& Wood, C.J. (in press). Inoceramid bivalves from the Coniacian (Upper Cretaceous) of the Staffhorst shaft (Lower Saxony, Germany) - Stratigraphical significance of a unique succession. Cretaceous Research (2017), http:/ /dx.doi.org/10.1016).

Walaszczyk, I., Dubicka, Z., Olszewska-Nejbert, D. \& Remin, Z., 2016. Integrated biostratigraphy of the
Santonian through Maastrichtian (Upper Cretaceous) of extra-Carpathian Poland. Acta Geologica Polonica 66, 313-350.

Walaszczyk, J., 2008. North Sudetic Basin (Outer Sudetic Cretaceous). [In:] T.P. McCann (Ed.): The Geology of Central Europe, 2. Mesozoic and Cenozoic. Geological Society of London, 959-960.

Weimer, R.J. \& Hoyt, J.H., 1964. Burrows of Callianassa mayor Say, geologic indicators of littoral and shallow neritic environments. Journal of Paleontology 38, 761767.

Wieczorek, J., 1979. Upper Jurassic nerineacean gastropods from the Holy Cross Mts. (Poland). Acta Palaeontologica Polonica 24, 299-350.

Woodward, S., 1830. A synoptic table of British Organic remains. London \& Norwich, Xiii +50pp.

Yanin, B.T. \& Baraboshkin, E.Yu., 2013. Thalassinoides Burrows (Decapoda Dwelling Structures) in Lower Cretaceous Sections of Southwestern and Central Crimea. Stratigraphy and Geological Correlation 21, 280-290.

Zekeli, F., 1852. Die Gastropoden der Gosaugebilde. Abhandlungen der Kaiserlich- Geologischen Reichanstalt, Abt. 2, Nr 2, p. 124, Taf. 24, Wien.

Zhang, L.-J. \& Zhao, Z., 2015. Lower Devonian trace fossils and their paleoenvironmental significance from the western Yangtze Plate, South China. Turkish Journal of Earth Sciences 24, 325-343.

Zhang, L.-J., Qi, Y.-A., Buatois, L.A., Mángano, M.G., Meng, Y. \& Li, D., 2017. The impact of deep-tier burrow systems in sediment mixing and ecosystem engineering in early Cambrian carbonate settings. Scientific Reports 7, 45773.

Zittel, K., 1866. Die Bivalven der Gosaugebilde in den nordöstlichen Alpen. Ein Beitrag zur Charakteristik der Kreideformation in Österreich. Denkschriften der Kaiserlichen Akademie der Wissenschaften, Mathematisch-Naturwissenschaftliche Classe 24. Wien, 105-178.

Żelaźniewicz, A. \& Aleksandrowski, P., 2008. Tectonic subdivision of Poland: southwestern Poland. Przeglad Geologiczny 56, 904-911 [in Polish with English summary].

Żelaźniewicz, A., Aleksandrowski, P., Buła, Z., Karnkowski, P.H., Konon, A., Oszczypko, N., Ślączka, A., Żaba, J. \& Żytko, K., 2011. Regionalizacja Tektoniczna Polski [Tectonic regionalization of Poland]. Komitet Nauk Geologicznych PAN, Wrocław, 60 pp. [in Polish].

Manuscript submitted 8 May 2017 Revision accepted 5 March 2018 